\title{
Essay
}

\section{Vigorous Race or Leisurely Walk: Reconsidering the Competition over Corporate Charters}

\author{
Lucian Arye Bebchuk ${ }^{\dagger}$ and Assaf Hamdani ${ }^{\dagger \dagger}$
}

\section{INTRODUCTION}

Does American corporate law work effectively to enhance shareholder value? The recent corporate governance crisis makes this time as good as any for reexamining the basic structure of this body of law. This Essay provides such a reconsideration of a defining feature of U.S. corporate law- - the existence of regulatory competition among states.

In the United States, most corporate law issues are left for state law, and corporations are free to choose where to incorporate and thus which state's corporate law system will govern their affairs. The dominant state in attracting the incorporations of publicly traded companies is, and for a long time has been, the small state of Delaware. ${ }^{1}$ Although Delaware is home to

$\dagger$ William J. Friedman \& Alicia Townsend Friedman Professor of Law, Economics, and Finance, Harvard Law School; Research Associate, National Bureau of Economic Research.

t† Associate, Goodwin Procter LLP, Boston; John M. Olin Fellow in Law and Economics, Harvard Law School.

We would like to thank Steve Bainbridge, Oren Bar-Gill, Michal Barzuza, Alma Cohen, Allen Ferrell, Jill Fisch, Tamar Frankel, Jesse Fried, Jeff Gordon, Marcel Kahan, Ehud Kamar, Barak Orbach, Mark Roe, Robert Sitkoff, and workshop and conference participants at Harvard and Toronto for helpful comments and discussions. We also wish to thank the Harvard Law School John M. Olin Center for Law, Economics, and Business for its financial support.

1. Delaware has dominated this market ever since the beginning of the last century when New Jersey, the market leader at the time, adopted rules that put firms incorporated in New Jersey at a disadvantage. See Curtis Alva, Delaware and the Market for Corporate Charters: History and Agency, 15 DEL. J. CORP. L. 885 (1990). 
less than one-third of a percent of the U.S. population, ${ }^{2}$ it is the incorporation jurisdiction of half of the publicly traded companies in the United States and of an even greater fraction of the larger publicly traded companies. ${ }^{3}$ Delaware thus plays a central role in setting corporate governance rules for the nation's publicly traded companies.

Why should this small state play such a critical role in the governance of the nation's corporate sector? At first glance, Delaware's existing dominant role might be viewed as inefficient or even illegitimate. ${ }^{4}$ The widely accepted justification for the existing state of affairs, however, is that Delaware's dominant role is a product of its winning a competition among states for providing desirable corporate law rules.

Indeed, the dominant view in corporate law scholarship is that allowing Delaware to dominate national corporate law is not a problematic feature, but rather an important virtue, indeed the "genius," of American corporate law. ${ }^{5}$ According to the prevailing view among corporate scholars, competition provides powerful incentives for adoption and development of value-enhancing corporate rules. ${ }^{6}$ Delaware has won its leading place by offering the best rules, and the competitive pressure it faces can be relied on to ensure that Delaware will continue to provide companies with whatever rules turn out to be best in our dynamic and changing business world.

The view that state competition works well rests on two propositions: (i) that states actively and vigorously compete for incorporations, and (ii) that the ensuing competitive threat provides the dominant state of Delaware, as well as other states, with powerful incentives to provide value-enhancing rules. Those skeptical of state competition have mainly focused on questioning the second proposition. Accepting that states actively compete for incorporations, such critics have argued that the

2. As of 2000 , Delaware had a population of about 783,000 , whereas the total population of the United States was about 281 million. U.S. CENSUS BUREAU, AGE: 2000 CENSUS BRIEF (2001), at http://www.census.gov/prod/2001 pubs/c2kbr01-12.pdf.

3. Delaware is the state of incorporation for fifty-seven percent of U.S. public companies and for fifty-nine percent of Fortune 500 companies. See infra tbl.2.

4. See Robert H. Sitkoff, Corporate Political Speech, Political Extortion, and the Competition for Corporate Charters, 69 U. CHI. L. REV. 1103, 1146 (2002) (arguing that Delaware "faces an ongoing potential popular legitimacy problem").

5. See generally ROBERTA ROMANO, THE GENIUS OF AMERICAN CORPORATE LAW (1993).

6. See, e.g., FRANK H. EASTERBROOK \& DANIEL R. FISCHEL, THE ECONOMIC STRUCTURE OF CORPORATE LAW 5-7 (1991); ROMANO, supra note 5, at 6-12; Michael Klausner, Corporations, Corporate Law, and Networks of Contracts, 81 VA. L. REV. 757, 842 (1995) (stating that "there is a broad consensus that state competition to produce corporate law is a race to (or at least toward) the top"); Ralph K. Winter, The "Race for the Top" Revisited: A Comment on Eisenberg, 89 COLUM. L. REV. 1526 (1989) [hereinafter Winter, Comment on Eisenberg]; Ralph K. Winter, Jr., State Law, Shareholder Protection, and the Theory of the Corporation, 6 J. LEGAL STUD. 251 (1977) [hereinafter Winter, State Law]. 
competitive threat might push states in undesirable directions with respect to some important corporate issues. ${ }^{\text {? }}$

In contrast, this Essay challenges the standard case for state competition by questioning the claim of the first proposition that states vigorously compete for incorporations. The alleged vigorous race among states vying for incorporations, we argue, simply does not exist. We present evidence that Delaware's dominant position is far stronger, and thus that the competitive threat that it faces is far weaker, than has been previously recognized. We also explain the underlying reasons for the weakness of competition in the market for incorporations. Furthermore, we show that the weakness of competition has major implications for both assessing the performance of state competition and determining the desirable role of federal law in this area.

Part II of this paper discusses the conventional premise that states compete actively for incorporations. We highlight the key role that this premise plays in the views of supporters of state competition. We also discuss how, at least for the purpose of the debate, critics of state competition have often accepted this premise.

Part III then discusses evidence indicating the absence of active competition among states for corporate charters. We pay close attention in this Part to the patterns of incorporations among states that have been documented in a recent empirical study by Alma Cohen and one of us. ${ }^{8}$ Although half of the publicly traded companies are incorporated outside Delaware, Delaware does not face any significant competitors in the business of attracting and serving out-of-state incorporations. The vast majority of non-Delaware corporations do not incorporate in a state that competes with Delaware over the hearts (or pockets) of firms incorporating out-of-state; rather, these firms simply remain incorporated in the state where they are headquartered.

In assessing the competitive threat facing Delaware, it is important to consider Delaware's position in the market for out-of-state incorporations. Among firms that do "shop" for out-of-state incorporations, Delaware

7. See, e.g., William L. Cary, Federalism and Corporate Law: Reflections upon Delaware, 83 YALE L.J. 663 (1974); Lucian Arye Bebchuk, Federalism and the Corporation: The Desirable Limits on State Competition in Corporate Law, 105 HARV. L. REV. 1435 (1992); Lucian Arye Bebchuk, Alma Cohen \& Allen Ferrell, Does the Evidence Favor State Competition in Corporate Law?, 90 CAL. L. RFV. (forthcoming 2002), available at http://papers.ssm.com/abstract=303417; Lucian Arye Bebchuk \& Allen Ferrell, Federalism and Corporate Law: The Race To Protect Managers from Takeovers, 99 COLUM. L. REV. 1168 (1999) [hereinafter Bebchuk \& Ferrell, Race To Protect Managers]; Lucian Arye Bebchuk \& Allen Ferrell, A New Approach to Takeover Law and Regulatory Competition, 87 VA. L. REV. 111 (2001) [hereinafter Bebchuk \& Ferrell, New Approach]; OREN BAR-GILL, Michal BarzUZA \& LUCIAN BebchUK, The MARKET FOR Corporate LAW (John M. Olin Ctr. for Law, Econ. \& Bus., Discussion Paper No. 377, 2002), at http://papers.ssrn.com/abstract $=275452$.

8. Lucian Bebchuk \& Alma Cohen, Firms' Decisions Where To Incorporate, 46 J.L. \& ECON. (forthcoming 2003), available at http://papers.ssrn.com/abstract=296492. 
captures approximately $85 \%$ of all incorporations. ${ }^{9}$ Delaware is thus a virtual monopoly in the out-of-state incorporations market, and no other state holds a significant position in this market. For example, whereas Delaware captures 216 out-of-state incorporations of Fortune 500 companies, no other state captures even 10 such incorporations, and the five states that follow Delaware's lead capture a total of 27 such out-of-state incorporations. ${ }^{10}$ Similarly, whereas Delaware captures about 3744 out-ofstate incorporations of publicly traded companies, each other state attracts fewer than 180 such incorporations. ${ }^{11}$ Furthermore, Delaware's longstanding dominance of the out-of-state incorporation market, and the larger incorporation market, has been growing. Indeed, examination of recent trends indicates that Delaware's dominance can be expected to keep growing even further in the near future. ${ }^{12}$

Its dominant position enables Delaware to make substantial supracompetitive profits. While Delaware's expenses on providing corporate law rules to the nation's firms are exceedingly small, it captures large franchise tax revenues - which on a per capita basis amount to $\$ 3000$ for each household of four-that constitute a large fraction of the state's budget. ${ }^{13}$ Still, notwithstanding these supracompetitive returns, other states have not been making any visible efforts to mount a serious challenge to Delaware's dominance. No state, as it were, has been giving Delaware a run for its money.

What explains Delaware's powerful and unchallenged dominance? Some states, especially large states for which such profits would not be significant, might well be simply indifferent to the prospect of making profits from the incorporation business. There are, however, enough small states in the United States for which profits such as those Delaware has been making would be quite attractive; such states would have had strong motivation to mount a challenge to Delaware's dominance if such a challenge could have been expected to succeed in enabling them to capture a significant fraction of these profits. That this has not been happening, notwithstanding Delaware's persistent supracompetitive returns, indicates in our view that mounting a challenge to Delaware has not been viewed as likely to be profitable.

9. As we explain below, we focus on the incorporation statistics of nonfinancial firms. See infra note 41 and accompanying text. Focusing on the numbers for all firms, including financial ones, does not materially change the picture. See Bebchuk \& Cohen, supra note 8, at 2.

10. See Bebchuk \& Cohen, supra note 8, tbl.13.

11. See id.

12. See id. at 5 .

13. In 2001, Delaware collected approximately $\$ 600$ million in franchise fees and had a population of 796,000. See U.S. Census Bureau, Delaware State Government TaX COLLECTIONS: 2001 (2002), at http://www.census.gov/govs/statetax/0108destax.html. 
Part IV analyzes the reasons for the absence of active competition. Drawing on the theory of industrial organization, we identify a number of structural features of the incorporation market that can explain why a challenge to Delaware's dominance by some other small state is unlikely to be profitable. The "product" currently offered by Delaware should be viewed as including not only its rules but also its institutional infrastructure, including Delaware's specialized chancery court, and the network benefits currently enjoyed by Delaware corporations. As a result, a state that would offer the same rules, but charge lower incorporation taxes and fees, would not be able to attract many out-of-state incorporations. Although its current incorporation taxes are in the aggregate meaningful for Delaware, such taxes never exceed $\$ 150,000$ for any given firm, and reductions in such expenditures are unlikely to lead firms incorporating out-of-state to forgo the benefits from the institutional infrastructure and network extemalities provided by Delaware. Similarly, a state that merely offers the same rules as Delaware with some marginal improvements cannot hope that such marginal improvements would by themselves attract many out-of-state incorporations.

The existing rules governing reincorporations further constrain the ability of a challenger to attract quickly a significant number of out-of-state incorporations. Reincorporations must be initiated by the board before being brought to a shareholder vote. Therefore, even if a rival state could identify a set of rules that could make shareholders substantially better off, this state would be unable to attract quickly many out-of-state incorporations unless the rules are also preferable for managers. This significantly narrows, of course, the scope of improvements in substantive rules on which a potential challenge could be based.

Finally, even if a rival were to identify some substantial set of changes that could significantly benefit both shareholders and management, and even if the rival were willing to invest up-front in institutional infrastructure, the profitability of a challenge could be undermined by the inability of the rival to launch a swift hit-and-run challenge. The substantial amount of time that would be required for the challenger to adopt changes and for firms to respond to them would provide Delaware with ample opportunity to react. Delaware could "match" by adopting the challenger's improved rules; Delaware's out-of-state incorporators might then stick with Delaware due to its initial network benefits, and the challenger would merely serve as a stalking horse pulling Delaware to improve its rules. Furthermore, even if the challenger were somehow able to capture a significant fraction of the out-of-state incorporation market, price competition between the challenger and Delaware would likely bring down prices; in this case, the challenger would bring down Delaware's current profits without being able to capture a substantial fraction of them. 
Part $\mathrm{V}$ turns to exploring the implications of the weak-competition account we develop for assessing the performance of state competition in corporate law. Our analysis indicates that the incentives of Delaware and of other states are likely to be quite different. Delaware is in the business of attracting and profiting from out-of-state incorporation. Its interests would be best served by policies that maintain its monopoly and undermine possible threats to it, and that increase the profits it makes from its position. In contrast, other states cannot, and do not expect to, obtain such a position in the out-of-state incorporation market, and maximizing revenues from such incorporations is thus irrelevant for such states. Accordingly, we examine separately the implications of our analysis for both Delaware law and the corporate law of other states.

Among other things, we show that our account of state competition undermines the view that rules produced by state competition should be regarded as presumptively efficient. Neither Delaware nor other states face the type of competitive situation in which a limited slack could gravely hurt a player's interests. We also explain how our account leads to the conclusion that states would tend to provide rules that, with respect to some issues, such as takeover protections, are more favorable to managers than would be optimal for shareholders.

Our weak-competition account suggests that the greatest threat confronting Delaware is not competition from other states but the possibility that the federal government will intervene in a way that would undermine Delaware's position. We discuss in Part V how, in light of this threat, Delaware's interests might be best served by providing a body of law that is largely judge-made and relies on open-ended and flexible standards. Furthermore, to the extent that Delaware is moved to act in shareholders' interests by the fear of triggering a federal intervention, this fear can provide a check only against rather large deviations from shareholder interests, and whatever benefits come from it should be attributed to the disciplinary role not of state competition but of federal fiat.

Finally, Part VI discusses the implications of the weak-competition account we put forward for the desirable role of federal law in this realm. The absence of strong competition undermines the basis for the view that Delaware's dominance is the product of its winning a vigorous competition. Thus, the analysis implies that the case for preferring state competition to mandatory federal rules is much weaker than supporters of state competition have assumed.

Furthermore, we argue that, given the weakness of existing competition, state competition, as currently structured, could in all likelihood be improved by using "choice-enhancing" federal intervention. This type of intervention, which has been put forward by Allen Ferrell and 
one of us in earlier work, could invigorate state competition..$^{14}$ In particular, it would be desirable for federal law to provide a federal incorporation option, as Canada's federal law does, as well as to enable shareholders to initiate and approve via a vote reincorporation to another state. Such federal intervention could introduce substantial and healthy competition in this market to the benefit of investors.

Although much of the work on state competition has taken as given the presence of active competition, there has been some prior work, upon which we build, discussing why Delaware has a dominant position. ${ }^{15}$ Among other things, earlier work has highlighted the significance of network externalities and legal infrastructure, which are important elements of our analysis. ${ }^{16}$

In a contemporaneous work, Marcel Kahan and Ehud Kamar also challenge the vigorous competition account of state competition, offering an analysis that complements ours. ${ }^{17}$ Kahan and Kamar persuasively document that states other than Delaware have not made a determined effort to attract and profit from out-of-state incorporations; this evidence

14. Bebchuk \& Ferrell, New Approach, supra note 7. For further development and reply to critics of the choice-enhancing approach, see Lucian Arye Bebchuk \& Allen Ferrell, Federal Intervention To Enhance Shareholder Choice, 87 VA. L. REV. 993 (2001) [hereinafter Bebchuk \& Ferrell, Reply to Critics I] (replying to a critical response by Stephen Choi and Andrew Guzman concerning the choice-enhancing approach); and Lucian Arye Bebchuk \& Allen Ferrell, On Takeover Law and Regulatory Competition, 2002 Bus. LAW. 1047 [hereinafter Bebchuk \& Ferrell, Reply to Critics II] (replying to a critical response by Jonathan Macey).

15. Noteworthy work includes the recent scholarship by Kahan and Kamar on how Delaware uses and maintains its market dominance. See Marcel Kahan \& Ehud Kamar, Price Discrimination in the Market for Corporate Law, 86 CORNELL L. REV. 1205 (2001) (arguing that Delaware makes substantial supracompetitive profits and increases these profits by using price discrimination practices, and noting that no state seems to have made a determined effort to compete with Delaware); Ehud Kamar, A Regulatory Competition Theory of Indeterminacy in Corporate Law, 98 Colum. L. REV. 1908 (1998) (arguing that Delaware's dominance is strengthened by its granting courts overly broad discretion that prevents other states from freeriding on its network extemalities).

We also build on earlier work discussing how network externalities and Delaware's legal infrastructure provide Delaware with a significant advantage. The presence of network externalities in this market was first highlighted by Klausner, supra note 6, at 841-51. The value of Delaware's specialized judiciary has been highlighted by the analysis of Bernard S. Black, Is Corporate Law Trivial?: A Political and Economic Analysis, 84 NW. U. L. REV. 542 (1990), Jill E. Fisch, The Peculiar Role of the Delaware Courts in the Competition for Corporate Charters, 68 U. CIN. L. REV. 1061 (2000), and Roberta Romano, Law as a Product: Some Pieces of the Incorporation Puzzle, 1 J.L. ECON. \& ORG. $225(1985)$. The term "leisurely walk" we use is taken from Winter, Comment on Eisenberg, supra note 6, at 1529, which noted the possibility that the race might be in fact a leisurely walk.

Finally, our argument with respect to the "stalking horse" problem builds on Bebchuk \& Ferrell, New Approach, supra note 7, at 154-55 (pointing out that this problem might deter rival states from challenging Delaware's dominance).

16. See Black, supra note 15; Fisch, supra note 15; Klausner, supra note 6, at 841-51; Romano, supra note 15.

17. See Marcel Kahan \& Ehud Kamar, The Myth of State Competition in Corporate Law, 55 STAN. L. REV. (forthcoming Dec. 2002), available at http:/hal-law.usc.edu/cleo/papers/ 02_5_paper.pdf. 
complements the evidence on which we focus concerning the patterns of incorporation among states. In explaining the absence of vigorous competition, Kahan and Kamar take a different approach from ours, arguing that states other than Delaware do not compete because state decisionmakers pursue political goals rather than profits. In contrast, we suggest that such a "political" story cannot adequately explain why other small states would not eagerly seek to capture Delaware's profits if they could do so; ${ }^{18}$ instead, we focus on "economic" explanations as to why they cannot do so, i.e., why attempts to capture these profits can be expected to fail. ${ }^{19}$

Our work differs from earlier and contemporaneous work by others in several important respects. First, we show that the patterns of incorporations indicate that Delaware's dominant position in the incorporations market is far stronger and more secure than has been previously recognized. Second, we provide a comprehensive analysis of the structural features of the market for corporate law-the "industrial organization" of this market - that make it unprofitable for other small states to challenge Delaware's position. Third, other works that have discussed imperfect competition in the incorporation market, including the contemporaneous work by Kahan and Kamar, have largely remained agnostic or even doubtful about the merits of federal intervention. ${ }^{20}$ In contrast, we show that the lack of meaningful competition in the incorporation market undermines the case for the existing system and provides an important basis for supporting a federal role.

Some of the points discussed in this Essay are more fully or rigorously developed in two companion pieces. An empirical study by Alma Cohen and one of us provides a comprehensive study of the patterns of incorporations, and we draw on it in Part III. ${ }^{21} \mathrm{~A}$ theoretical work by Oren Bar-Gill, Michal Barzuza, and one of us develops the first formal model of

18. See infra Section III.F.

19. Kahan and Kamar briefly discuss "economic" entry barriers, expressing doubt that they could be significant enough to discourage entry by other states, and therefore focus on political goals and political constraints that move states away from the pursuit of profits. Kahan \& Kamar, supra note 17 (manuscript at 66-69) (concluding that the lack of determined efforts by other states "lies in political, rather than economic, factors").

20. See, e.g., id. (manuscript at 8-9) (noting that "federal law may be no better and, in particular, may give even less weight to shareholder interests than Delaware law does"); Kahan \& Kamar, supra note 15, at 1252 (stating that their account of the market is compatible with both the view that state competition is desirable and the view that it is not); Kamar, supra note 15, at 1948 (stating that his depiction of the strategic indeterminacy of Delaware's corporate law "is consistent with both the race-to-the-top and the race-to-the-bottom theories").

Imperfect competition arguments have been used to call for federal intervention, however, in another work by one of us. See Bebchuk \& Ferrell, New Approach, supra note 7, at 154-55 (discussing how the "stalking horse" problem, which we further develop in this Essay, deters rival states from challenging Delaware's dominance and strengthens the case for a body of optional federal law).

21. See Bebchuk \& Cohen, supra note 8. 
state competition over incorporations; ${ }^{22}$ this model pays close attention to the industrial organization features of the incorporation market, and we build on its insights in Part IV.

\section{The CONVENTIONAL PREMISE OF Vigorous COMPETITION}

As stressed in the Introduction, the premise that states vigorously compete for incorporations is widely shared in the corporate literature. To begin, this premise is a critical building block of the standard case for state competition in corporate law. For example, Ralph Winter, an early and prominent supporter of such competition, begins from the premise that "an important mechanism generating change in American corporate law has ... been the competition among the states for charters," that "Delaware cannot create barriers," and that "any attempt at monopolization will only drive capital from that state." ${ }^{, 23}$ Daniel Fischel, another early supporter, characterizes the existing state of affairs as "a system of fifty states striving to create an attractive climate for private parties to maximize their joint welfare. ${ }^{24}$ Roberta Romano, a supporter of state competition and the most influential writer on state competition in the past decade, stresses that "states do compete for the chartering business."

From this premise of active competition, supporters of state competition have proceeded to argue that this competition works to the benefit of shareholders. On their view, states that offer the best rules will attract the most incorporations, and competition for incorporations will thus drive states to offer such rules. ${ }^{26}$ The competition provides incentives to offer not just rules but also institutions, such as specialized courts, that operate to increase shareholder value. Another benefit of competition in the view of its supporters is "dynamic": States will have incentives to innovate and develop better arrangements and to adopt quickly beneficial innovations that will be produced by others. ${ }^{27}$ Yet another benefit arises

22. See BAR-GILL, BARZUZA \& BEBCHUK, supra note 7.

23. Winter, State Law, supra note 6, at 255-58.

24. Daniel R. Fischel, The "Race to the Bottom" Revisited: Reflections on Recent Developments in Delaware's Corporation Law, 76 NW. U. L. REV. 913, 922 (1982) (emphasis added); see also EASTERBROOK \& FISCHEL, supra note 6 , at 6 (observing that "states compete to offer-and managers to use-beneficial sets of legal rules").

25. ROMANO, supra note 5, at 16 (emphasis added). Romano offers a refined account of the competitive process. Under her depiction, which she labels "defensive competition," most states compete to maintain their position and not to enlarge their market share. See Romano, supra note 15, at 236; Roberta Romano, The Need for Competition in International Securities Regulation, 2 THEORETICAL INQUIRIES L, 387 (2001).

26. See, e.g., Frank H. Easterbrook \& Daniel R. Fischel, The Corporate Contract, 89 CoLuM. L. REV. 1416, 1416-17 (1989).

27. See Roberta Romano, Empowering Investors: A Market Approach to Securities Regulation, 107 YALE L.J. 2359, 2392 (1998) (positing that the current regime of corporate federalism facilitates successful innovations in the realm of corporate law). 
from the heterogeneity among firms: Whereas most states might offer arrangements that are commonly beneficial, some states might seek to gain incorporations by developing a niche and providing rules attractive for a certain special type of firm. ${ }^{28}$

All this has led supporters of state competition to view it as a powerful mechanism working to benefit shareholders-indeed, in the words of a prominent supporter, state competition is the "genius of American corporate law." 29 It is thus not surprising that, concerned that the federal government is not subject to such beneficial competitive pressure, these supporters strongly oppose any federal role in the area of corporate law. ${ }^{30}$ Indeed, viewing the competition among states as having worked wonders for corporate law, several scholars have recently called for a regime of unlimited regulatory competition among countries in the area of securities regulation. ${ }^{31}$

Turning from supporters of state competition to critics, it is important to observe that the latter generally have not sought to challenge the premise of the supporters of state competition that states actively compete for incorporations. Rather, taking as given this premise for the purpose of their analysis, they have questioned the implications that supporters of state competition draw from this premise. In particular, critics have questioned whether competitive pressure on states would generally push them to adopt desirable rules. Competitive pressure, they have argued, might produce counterproductive effects with respect to certain important issues.

28. See Richard A. POSNER \& KENNETH E. SCOTT, ECONOMICS OF CORPORATION LAW AND SECURITIES REGULATION 111 (1980) (suggesting that Delaware specializes in charters for large public corporations); Barry D. Baysinger \& Henry N. Butler, The Role of Corporate Law in the Theory of the Firm, 28 J.L. \& ECON. 179 (1985) (arguing that variations in corporate codes match divergent capital structures - companies with more-concentrated share ownership will tend to prefer codes providing less discretion to managers than Delaware's code). But see RoMANO, supra note 5, at 45-48 (questioning the validity of these product-differentiation arguments). In a different context, Professor Coffee argues that global competition among securities markets would lead markets to specialize. See JoHN C. COFFEE JR., COMPETITION AMONG SECURITIES MARKETS: A PATH DEPENDENT PERSPECTIVE (Columbia Law Sch. Ctr. for Law \& Econ. Studies, Working Paper No. 192, 2001), at http://papers.ssm.com/abstract=283822 (predicting the emergence of two types of specialized markets for securities: one for companies with dispersed ownership and one for companies with concentrated ownership).

29. ROMANO, supra note 5.

30. See, e.g., RICHARD A. POSNER, ECONOMIC ANALYSIS OF LAW 458-59 (5th ed. 1998) (arguing that "[c]ompetition among states to attract corporations should result in optimal rules of corporate law" and that a "preemptive federal corporation law would carry no similar presumption of optimality").

31. See Stephen J. Choi \& Andrew T. Guzman, Portable Reciprocity: Rethinking the International Reach of Securities Regulation, 71 S. CAL. L. REV. 903 (1998); Romano, supra note 27, at 2418-27; Romano, supra note 25. But see Robert Bloomfield \& Maureen O'Hara, Can Transparent Markets Survive?, 55 J. FIN. ECON. 425 (2000) (predicting that international competition in securities regulation will result in a "race to the bottom"); Merritt B. Fox, Retaining Mandatory Securities Disclosure: Why Issuer Choice Is Not Investor Empowerment, 85 VA. L. REV. 1335 (1999) (opposing proposals for international competition in securities regulation). 
Critics have argued, for example, that competition for incorporations might induce states to offer freezeout rules that are excessively favorable to controlling shareholders. ${ }^{32}$ Similarly, critics have argued that competitive pressure might lead states to adopt rules that are overly favorable to managers and controlling shareholders with respect to issues that (i) have a major effect on private benefits of control (are "significantly redistributive"), or (ii) directly affect the strength of market discipline. ${ }^{33}$ Recent evidence that states that have amassed antitakeover statutes have been more successful in attracting incorporation is consistent with this critique of state competition. ${ }^{34}$

Whereas this line of work has been skeptical of the virtues of subjecting the providers of corporate rules to competitive pressures (at least as currently structured), it has not questioned the premise that there is an active and vigorous competition. Rather, the presence of competition is a premise of this line of work. Indeed, the stronger the competitive pressure, the more severe the adverse effects suggested by this work. For this reason, accounts of the debate on state competition have often observed that, notwithstanding their substantial disagreements about the consequences of competition, participants in the debate generally accept that states actively compete to attract incorporations. ${ }^{35}$

As we now turn to show, however, there is another basis for questioning the case for state competition. The evidence we put forward in the next Part indicates that the vigorous race among states, whose presence is a key premise underlying the case for state competition, does not exist in fact.

\section{THE ABSENCE OF VIGOROUS COMPETITION: EVIDENCE}

This Part discusses empirical evidence indicating the weakness of competition in the market for out-of-state incorporations dominated by Delaware. Section A looks at the distribution of incorporations among states. Section B examines the strong home-state bias affecting firms' incorporation decisions. Section C examines Delaware's absolute dominance of the market for out-of-state incorporations. Section D

32. See Cary, supra note 7 , at 665-66 (describing the erosion of shareholder rights produced by the competition among states over incorporations and coining the term "race for the bottom" to describe this phenomenon).

33. See Bebchuk, supra note 7, at 1441, 1467.

34. Bebchuk, Cohen \& Ferrell, supra note 7; Guhan Subramanian, The Influence of Antitakeover Statutes on Incorporation Choice: Evidence on the "Race" Debate and Antitakeover Overreaching, 150 U. PA. L. REV. 1795 (2002); Bebchuk \& Cohen, supra note 8, at 15-26.

35. See Mark J. Loewenstein, Delaware as Demon: Twenty-Five Years After Professor Cary's Polemic, 71 U. COLO. L. REV. 497, 502 (2000) (observing that "it is the accepted wisdom that states do compete" in the market for corporate incorporations); Romano, supra note 15 , at 227-29 (reviewing the common assumptions shared by the two scholarly camps). 
discusses the absence of significant efforts by other states to challenge Delaware's dominance of this market. Section E looks at the large supracompetitive profits enjoyed by Delaware. Section $F$ discusses the question raised by the evidence-why the competitive threat faced by Delaware is so weak-which Part IV will subsequently seek to address.

\section{A. Where Do Firms Incorporate?}

The question of state competition has produced a voluminous literature in the last three decades. Nevertheless, surprisingly little effort has been taken to examine the actual patterns of incorporations. Although there has been substantial empirical work on the general subject of state competition, this work has largely focused on studying the effects on shareholder wealth of incorporation in, or reincorporation to, Delaware. ${ }^{36}$ In terms of the distribution of incorporations, this literature generally has only observed Delaware's large market position. ${ }^{37}$ In this context, studies either refer to the official data provided by the state of Delaware, which indicate that Delaware is the incorporation venue for roughly fifty percent of publicly traded firms ${ }^{38}$ or note similar figures for Delaware incorporation among the firms in their database. ${ }^{39}$

36. See, e.g., Michael Bradley \& Cindy A. Schipani, The Relevance of the Duty of Care Standard in Corporate Governance, 75 IowA L. REV. 1 (1989); Peter Dodd \& Richard Leftwich, The Market for Corporate Charters: "Unhealthy Competition" Versus Federal Regulation, 53 J. BUS. 259 (1980); Randall Heron \& Wilbur G. Lewellen, An Empirical Analysis of the Reincorporation Decision, 33 J. FIN. \& QUANTITATIVE ANALYSIS 549 (1998); Jeffry Netter \& Annette Poulson, State Corporation Laws and Shareholders: The Recent Experience, $18 \mathrm{~J}$. FIN. MGMT. Ass'N 29 (1989); Pamela Peterson, Reincorporation: Motives and Shareholder Wealth, 23 FIN. REV. 151 (1988); Romano, supra note 15. For a recent survey and critique of the empirical work on the wealth effects of Delaware incorporation, see Bebchuk, Cohen \& Ferrell, supra note 7.

37. See, e.g., Melvin Aron Eisenberg, The Structure of Corporation Law, 89 CoLUM. L. REv. 1461, 1512-13 (1989) (noting that Delaware has market power); Fisch, supra note 15 (seeking to explain Delaware's dominant position based on the unique role of its judiciary).

38. See Del. Div. of Corps., Home Page, at http://www.state.de.us/corp/index.htm (last modified Oct. 2002) (stating that $50 \%$ of the companies listed on the New York Stock Exchange and $60 \%$ of the Fortune 500 companies are incorporated in Delaware). For representative examples of commentators relying on such data, see Kahan \& Kamar, supra note 15, at 1210 (noting, in reliance on Delaware's website, that about half of U.S. public corporations are incorporated in Delaware); and Roberta Romano, Competition for Corporate Charters and the Lesson of Takeover Statutes, 61 FORDHAM L. REV. 843, 845 (1993) (stating that roughly half of the largest industrial firms are incorporated in Delaware).

In addition, several studies have noted the fraction of companies reincorporating in Delaware. See Dodd \& Leftwich, supra note 36, at 263 (finding that between 1927 and 1977, 90\% of reincorporations were in Delaware); Demetrios G. Kaouris, Is Delaware Still a Haven for Incorporation?, 20 DEL. J. CORP. L. 965, 999 (1995) (reporting that out of 255 surveyed companies that changed domicile between 1982 and 1994, 89\% reincorporated in Delaware); Romano, supra note 15, at 244 (finding that between 1960 and 1983 , about $82 \%$ of reincorporations were in Delaware).

39. See Robert Daines, Does Delaware Law Improve Firm Value?, 62 J. FIN. ECON. 525, 538 (2001) (reporting that Delaware has a share of $55.8 \%$ of public companies in his 1996 sample). 
What has been missing in the debate is an account of where the large fraction of firms that incorporate outside Delaware choose to incorporate. The full division of the market is, of course, necessary for assessing whether any states are presently posing a competitive challenge, offering Delaware a "run for its money," and, if so, which are those states. Similarly needed is evidence on the segments of the market in which Delaware does better and worse, and how Delaware's share in these segments, and as a result in the market as a whole, has been developing. As students of industrial organization know, such evidence would be useful for assessing the strength of the competitive threat confronting Delaware.

A recent study by Alma Cohen and one of us has documented the patterns of incorporations and thus, in turn, the structure of the incorporations market, and we discuss the findings of this study below. ${ }^{40}$ This study is based on examining the data available in Compustat, a widely used database, on all exchange-traded firms that were both headquartered and incorporated in the United States. The identified patterns we report below exclude financial firms, following Robert Daines, and focus on the set of all nonfinancial firms. ${ }^{4}$ At the end of 1999 , there were 6,530 publicly traded nonfinancial firms that were both incorporated and headquartered in the United States.

Table 1 presents the distribution of U.S. companies by state of location. By state of location we mean throughout the state where the firm's headquarters are located (which is the information included in Compustat). The table presents (as do subsequent tables) the distribution of companies not only for all publicly traded firms, but also for all Fortune 500 companies and all companies going public in the five-year period 19962000.

40. See Bebchuk \& Cohen, supra note 8. All the Tables displayed below are adapted from this study, which includes a detailed discussion of the procedures used for reaching its findings. A recent study by Subramanian, supra note 34, also reports the distribution of firms among states of incorporation, but he does not document the patterns of home-state advantage and the growing dominance of Delaware over time, findings on which we focus below.

41. See Daines, supra note 39 , at 530 (excluding financial firms for several reasons, including the different regime governing the takeovers of these firms). 
TABle 1. Distribution OF COMPany HeAdQuarters Among STATES (ALl NonfinanCIAL PUblicly TRAded Firms)*

\begin{tabular}{|c|c|c|c|c|c|c|c|c|}
\hline \multicolumn{3}{|c|}{$\begin{array}{l}\text { All Publicly Traded } \\
\text { Companies }\end{array}$} & \multicolumn{3}{|c|}{ Fortune 500 Companies } & \multicolumn{3}{|c|}{$\begin{array}{c}\text { Companies That Went } \\
\text { Public During } 1996-2000\end{array}$} \\
\hline State & $\begin{array}{l}\text { Number } \\
\text { of Firms }\end{array}$ & Percentage & State & $\begin{array}{l}\text { Number } \\
\text { of Firms }\end{array}$ & Percentage & State & $\begin{array}{l}\text { Number } \\
\text { of Firms }\end{array}$ & Percentage \\
\hline Total & 6530 & $100 \%$ & Total & 370 & $100 \%$ & Total & 2010 & $100 \%$ \\
\hline $\mathrm{CA}$ & 1254 & $19.20 \%$ & $\mathrm{CA}$ & 41 & $11.08 \%$ & $\mathrm{CA}$ & 549 & $27.31 \%$ \\
\hline $\mathrm{TX}$ & 586 & $8.97 \%$ & $\mathrm{TX}$ & 36 & $9.73 \%$ & $\mathrm{TX}$ & 172 & $8.56 \%$ \\
\hline $\mathrm{NY}$ & 576 & $8.82 \%$ & $\mathrm{NY}$ & 32 & $8.65 \%$ & $\mathrm{NY}$ & 165 & $8.21 \%$ \\
\hline $\mathrm{MA}$ & 360 & $5.51 \%$ & $\mathrm{IL}$ & 31 & $8.38 \%$ & $\mathrm{MA}$ & 137 & $6.82 \%$ \\
\hline FL & 328 & $5.02 \%$ & PA & 22 & $5.95 \%$ & FL & 113 & $5.62 \%$ \\
\hline $\mathrm{NJ}$ & 311 & $4.76 \%$ & $\mathrm{OH}$ & 21 & $5.68 \%$ & $\mathrm{CO}$ & 67 & $3.33 \%$ \\
\hline $\mathrm{PA}$ & 248 & $3.80 \%$ & NI & 18 & $4.86 \%$ & NJ & 66 & $3.28 \%$ \\
\hline IL & 241 & $3.69 \%$ & $\mathrm{MI}$ & 14 & $3.78 \%$ & $\mathrm{GA}$ & 62 & $3.08 \%$ \\
\hline $\mathrm{MN}$ & 212 & $3.25 \%$ & $\mathrm{MO}$ & 14 & $3.78 \%$ & PA & 60 & $2.99 \%$ \\
\hline $\mathrm{CO}$ & 201 & $3.08 \%$ & VA & 13 & $3.51 \%$ & IL & 56 & $2.79 \%$ \\
\hline $\mathrm{OH}$ & 192 & $2.94 \%$ & $\mathrm{FL}$ & 12 & $3.24 \%$ & $\overline{W A}$ & 55 & $2.74 \%$ \\
\hline $\mathrm{GA}$ & 178 & $2.73 \%$ & $\mathrm{GA}$ & 12 & $3.24 \%$ & $\mathrm{VA}$ & 51 & $2.54 \%$ \\
\hline $\mathrm{VA}$ & 154 & $2.36 \%$ & $\mathrm{MN}$ & 10 & $2.70 \%$ & $\mathrm{MN}$ & 48 & $2.39 \%$ \\
\hline $\mathrm{CT}$ & 148 & $2.27 \%$ & $\mathrm{CT}$ & 9 & $2.43 \%$ & $\mathrm{CT}$ & 44 & $2.19 \%$ \\
\hline WA & 131 & $2.01 \%$ & $\mathrm{NC}$ & 8 & $2.16 \%$ & MD & 40 & $1.99 \%$ \\
\hline MI & 104 & $1.59 \%$ & WA & 8 & $2.16 \%$ & $\mathrm{NC}$ & 29 & $1.44 \%$ \\
\hline $\mathrm{MD}$ & 101 & $1.55 \%$ & $\mathrm{MA}$ & 7 & $1.89 \%$ & $\mathrm{OH}$ & 29 & $1.44 \%$ \\
\hline $\mathrm{MO}$ & 101 & $1.55 \%$ & $\mathrm{MD}$ & 5 & $1.35 \%$ & $A Z$ & 27 & $1.34 \%$ \\
\hline $\mathrm{NC}$ & 98 & $1.50 \%$ & $\mathrm{TN}$ & 5 & $1.35 \%$ & $\mathrm{MI}$ & 23 & $1.14 \%$ \\
\hline $\mathrm{AZ}$ & 91 & $1.39 \%$ & WI & 5 & $1.35 \%$ & $\mathrm{MO}$ & 23 & $1.14 \%$ \\
\hline TN & 81 & $1.24 \%$ & AL & 4 & $1.08 \%$ & TN & 21 & $1.04 \%$ \\
\hline WI & 72 & $1.10 \%$ & $\mathbf{A R}$ & 4 & $1.08 \%$ & UT & 17 & $0.85 \%$ \\
\hline $\mathrm{OR}$ & 70 & $1.07 \%$ & $\mathrm{AZ}$ & 4 & $1.08 \%$ & $\mathrm{NV}$ & 15 & $0.75 \%$ \\
\hline UT & 70 & $1.07 \%$ & $\mathrm{CO}$ & 4 & $1.08 \%$ & $L A$ & 13 & $0.65 \%$ \\
\hline $\mathrm{NV}$ & 63 & $0.96 \%$ & $\mathrm{DE}$ & 4 & $1.08 \%$ & OR & 13 & $0.65 \%$ \\
\hline Other & 560 & $8.58 \%$ & Other & 27 & $7.30 \%$ & Other & 115 & $5.72 \%$ \\
\hline
\end{tabular}

* The data in this and all subsequent tables exclude financial companies. Tables based on data that include financial companies are available from the authors upon request.

Not surprisingly, a large number of firms are located in states with large populations and big economies. California, for example, with the biggest population and economy, is home to $19.2 \%$ of all companies. Texas comes second, with approximately $9 \%$ of all companies. California's share is especially large (27.3\%) among companies that went public in 1996-2000, 
presumably because of the large number of Silicon Valley companies going public in those years.

Table 2 displays the distribution of U.S. companies by their state of incorporation.

TABLE 2. DISTRIBUTION OF COMPANIES

BY STATE OF INCORPORATION

\begin{tabular}{|c|c|c||c|c|c||c|c|c|}
\hline \multicolumn{2}{|c|}{$\begin{array}{c}\text { All Publicly Traded } \\
\text { Companies }\end{array}$} & \multicolumn{2}{|c|}{ Fortune 500 Companies } & \multicolumn{3}{|c|}{$\begin{array}{c}\text { Companies That Went } \\
\text { Public During 1996-2000 }\end{array}$} \\
\hline \begin{tabular}{c|c|c|c|c|c|c|c|c|c|} 
State \\
Number \\
of Firms
\end{tabular} & Percentage & State & $\begin{array}{c}\text { Number } \\
\text { of Firms }\end{array}$ & Percentage & State & $\begin{array}{c}\text { Number } \\
\text { of Finns }\end{array}$ & Percentage \\
\hline Total & 6530 & $100 \%$ & Total & 370 & $100 \%$ & Total & 2010 & $100 \%$ \\
\hline DE & 3771 & $57.75 \%$ & DE & 220 & $59.46 \%$ & DE & 1364 & $67.86 \%$ \\
\hline CA & 283 & $4.33 \%$ & NY & 22 & $5.95 \%$ & CA & 90 & $4.48 \%$ \\
\hline NY & 226 & $3.46 \%$ & OH & 13 & $3.51 \%$ & NV & 72 & $3.58 \%$ \\
\hline NV & 217 & $3.32 \%$ & PA & 12 & $3.24 \%$ & FL & 58 & $2.89 \%$ \\
\hline MN & 178 & $2.73 \%$ & NJ & 11 & $2.97 \%$ & TX & 45 & $2.24 \%$ \\
\hline FL & 165 & $2.53 \%$ & VA & 9 & $2.43 \%$ & CO & 37 & $1.84 \%$ \\
\hline TX & 147 & $2.25 \%$ & MD & 8 & $2.16 \%$ & MN & 36 & $1.79 \%$ \\
\hline CO & 132 & $2.02 \%$ & FL & 7 & $1.89 \%$ & WA & 34 & $1.69 \%$ \\
\hline PA & 124 & $1.90 \%$ & IN & 6 & $1.62 \%$ & GA & 30 & $1.49 \%$ \\
\hline MA & 118 & $1.81 \%$ & CA & 5 & $1.35 \%$ & MA & 27 & $1.34 \%$ \\
\hline OH & 112 & $1.72 \%$ & GA & 5 & $1.35 \%$ & NY & 22 & $1.09 \%$ \\
\hline NJ & 111 & $1.70 \%$ & MI & 5 & $1.35 \%$ & PA & 22 & $1.09 \%$ \\
\hline GA & 83 & $1.27 \%$ & NC & 5 & $1.35 \%$ & OH & 19 & $0.95 \%$ \\
\hline WA & 79 & $1.21 \%$ & NV & 5 & $1.35 \%$ & MD & 16 & $0.80 \%$ \\
\hline VA & 74 & $1.13 \%$ & MN & 4 & $1.08 \%$ & VA & 15 & $0.75 \%$ \\
\hline MI & 60 & $0.92 \%$ & MO & 4 & $1.08 \%$ & NJ & 13 & $0.65 \%$ \\
\hline WI & 57 & $0.87 \%$ & TX & 4 & $1.08 \%$ & MI & 12 & $0.60 \%$ \\
\hline MD & 54 & $0.83 \%$ & WA & 4 & $1.08 \%$ & TN & 12 & $0.60 \%$ \\
\hline OR & 54 & $0.83 \%$ & WI & 4 & $1.08 \%$ & OR & 11 & $0.55 \%$ \\
\hline UT & 52 & $0.80 \%$ & IL & 3 & $0.81 \%$ & UT & 11 & $0.55 \%$ \\
\hline NN & 50 & $0.77 \%$ & KS & 3 & $0.81 \%$ & NC & 10 & $0.50 \%$ \\
\hline NC & 46 & $0.70 \%$ & KY & 2 & $0.54 \%$ & WI & 9 & $0.45 \%$ \\
\hline TN & 39 & $0.60 \%$ & MA & 2 & $0.54 \%$ & LA & 7 & $0.35 \%$ \\
\hline MO & 36 & $0.55 \%$ & OR & 2 & $0.54 \%$ & MO & 7 & $0.35 \%$ \\
\hline IL & 32 & $0.49 \%$ & HI & 1 & $0.27 \%$ & IN & 6 & $0.30 \%$ \\
\hline Other & 230 & $3.52 \%$ & Other & 4 & $1.08 \%$ & Other & 25 & $1.24 \%$ \\
\hline
\end{tabular}

Imaged with the Permission of Yale Law Journal 
As expected, Delaware has by far the largest stake of incorporations: $57.75 \%$ of all public companies. Delaware's share is even larger with respect to Fortune 500 companies (59\%), and companies that went public in $1996-2000(68 \%)$. These figures are generally consistent with the literature's estimates of Delaware's large market share. As we argue below, however, focusing on these figures leads to underestimation of Delaware's actual dominance of the incorporation market.

Comparing Tables 1 and 2 reveals that the distributions of corporations by state of location and state of incorporation are quite different. California, for example, is the state of location for $27.3 \%$ of public companies, but only $4 \%$ of public companies choose California as their state of incorporation. In contrast, Delaware, where approximately $58 \%$ of public companies incorporate, is the state of location for less than $0.9 \%$ of publicly traded companies.

\section{B. Home-State Bias and Its Implications}

\section{Presence}

The evidence presented thus far does not tell us where the large fraction of non-Delaware firms incorporate. Do these firms incorporate in states that, like Delaware but on a smaller scale, are active and somewhat successful in the business of attracting out-of-state incorporations? Might it be that, in addition to Delaware with $58 \%$ of the market, there are other substantial players, each holding, say, a $15 \%$ share of the market? Such smaller but still substantial competitors could provide Delaware with a competitive threat. As we shall now see, this is far from being the case.

Table 3 presents a matrix displaying the web of company migrations. The table indicates for each state how the firms located in it divide their incorporations between this state and all other states.

A noticeable feature of Table 3 is the large numbers in the boxes along the diagonal, which contain the numbers of in-state incorporations for each and every state. The large concentration of firms along this diagonal suggests the possible presence of a significant "home-state advantage" or a "home-state bias." Even states that are hardly able to attract out-of-state companies (i.e., whose corporate law system is rarely "purchased" by outof-state "buyers") generally succeed in retaining a significant fraction of their in-state companies.

Overall, there is an enormous difference between states' attractiveness to in-state and out-of-state companies. For example, California, which does relatively poorly on both dimensions, still performs far better for in-state 
firms, retaining $22 \%$ of them, than for out-of-state firms, attracting only $0.2 \%$ of them. ${ }^{42}$ Altogether, California is the incorporation choice of 273 firms located in California but only 10 firms located elsewhere. A regression analysis confirms that being located in California hugely increases, in a statistically significant way, the likelihood that a company will incorporate in California. ${ }^{43}$ It is worth noting that this home-state advantage is not unique to any particular subset of the states, but rather characterizes states across the board.

42. See Bebchuk \& Cohen, supra note 8 , tbl.5.

43. See id. tbl.6. 
TABLE 3. LOCATION AND INCORPORATION

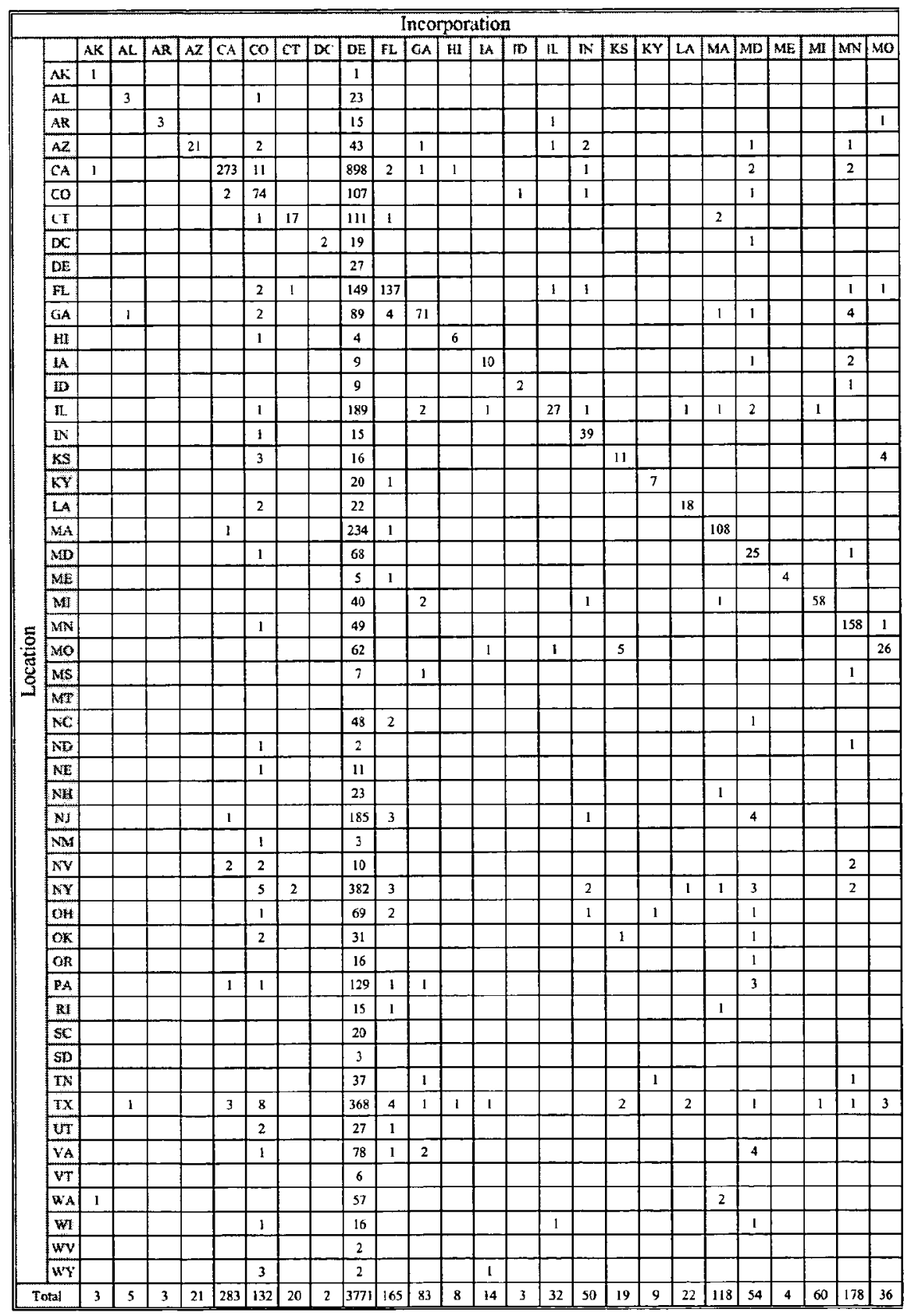


TABLE 3. (CONT.)

\begin{tabular}{|c|c|c|c|c|c|c|c|c|c|c|c|c|c|c|c|c|c|c|c|c|c|c|c|c|c|c|c|}
\hline \multicolumn{28}{|c|}{ Incorporation } \\
\hline \begin{tabular}{|l|} 
MS \\
\end{tabular} & $\mathrm{MT}$ & iNe & No & $N E$ & $\mathrm{NH}$ & $\mathrm{NS}$ & $\mathrm{NM}$ & Ny & $\mathrm{sy}$ & OH & $O K$ & OR & $\mathrm{PA}$ & RJ & $\mathrm{sc}$ & SOD & $\pi$ & $n$ & UT & $V_{A}$ & $\mathrm{vT}$ & WA & w1 & wr & WY & frotal & \\
\hline & & & & & & & & & & & & & & & & & & & & & & & & & & 2 & $\mathbf{A K}$ \\
\hline & & & & & & 1 & & & & & & & & & & & 1 & & & & & & & & & 29 & $\mathrm{Al}_{\text {. }}$ \\
\hline & & & & & & & & & & & & & & & & & & & & & & & & & & 20 & $A R$ \\
\hline & & & & & & 2 & & 9 & 3 & & & & 1 & & & & & 1 & 1 & & & & & & 2 & 91 & $\mathrm{AZ}$ \\
\hline & & & & 1 & & 4 & 1 & 34 & 6 & 1 & & 1 & & & 1 & & 2 & 1 & 7 & & & 2 & & & 1 & 1254 & $\mathrm{CA}$ \\
\hline & & & & & & & 1 & 7 & 2 & & & & & & & & & 1 & 1 & & & 1 & & & 2 & 201 & $\infty$ \\
\hline & & & & & & 1 & & 2 & 8 & & & & & & & & & & & 3 & & & 1 & & & 147 & $\mathrm{CT}^{\mathrm{T}}$ \\
\hline & & & & & & & & & 2 & & & & & & & & & & & & & 1 & & & & \begin{tabular}{|l|l}
25 & \\
\end{tabular} & DE \\
\hline & & & & & & & & & & & & & & & & & & & & & & & & & & 27 & $\mathrm{DE}$ \\
\hline & & 2 & & 1 & & 3 & & 15 & 9 & & & & 1 & & & & & 1 & 1 & 1 & & & & & 1 & \begin{tabular}{|l|l}
328 \\
\end{tabular} & $\mathrm{FE}$ \\
\hline & & 1 & & & & & & & 1 & 1 & & & 1 & & & & & 1 & & & & & & & & 178 & OA \\
\hline & & & & & & & & 1 & & & & & & & & & & & 1 & & & & & & & 13 & $\mathrm{HI}$ \\
\hline & & & & 1 & & & & 2 & & & & & & & & & & & & & & & & & & 25 & IA \\
\hline & & & & & & & & 2 & & & & & & & & & & & & & & 1 & & & & 15 & ID \\
\hline & & & & & & 1 & & 2 & 5 & & 1 & & 2 & & & & & & 1 & 2 & & & 1 & & & 241 & $\mathrm{n}$ \\
\hline & & & & & & & & & & & & & & & & & & & & 1 & & & & & & \begin{tabular}{|l|l}
56 \\
\end{tabular} & $\mathbb{N}$ \\
\hline & & & & & & & & & 1 & & & & & & & & & & & & & & & & & 35 & $\mathrm{ks}$ \\
\hline & & 1 & & & & & & & & & & & & & & & & & & & & & & & & 29 & $\mathrm{KY}$ \\
\hline & & & & & & & & 3 & & & & & & & & & & & & & & & & & & 45 & $\mathrm{LA}$ \\
\hline & & & & & & 3 & & 4 & 3 & & 1 & & 4 & 1 & & & & & & & & & & & & \begin{tabular}{|l|l|}
360 \\
\end{tabular} & $\mathrm{MA}$ \\
\hline & & 1 & & & & & & 1 & 2 & & & & & & & & & & & 2 & & & & & & \begin{tabular}{|l|}
101 \\
\end{tabular} & $M D$ \\
\hline & & & & & & & & & & & & & & & & & & & & & & & & & & \begin{tabular}{|l|l|}
10 \\
\end{tabular} & ME \\
\hline & & & & & & & & & 1 & 1 & & & & & & & & & & & & & & & & \begin{tabular}{|l|l|}
104 \\
\end{tabular} & $\mathrm{MI}$ \\
\hline & & & & & & & & 2 & & & & & & & & & & & 1 & & & & & & & \begin{tabular}{|l|l|}
212 \\
\end{tabular} & $\mathrm{MN}$ \\
\hline & & & & & & 1 & & 1 & 3 & & & & & & & & & & 1 & & & & & & & 101 & $M O$ \\
\hline 4 & & & & & & & & & & & & & & & & & 1 & & & & & & & & & 14 & MS \\
\hline & 6 & & & & & & & & & & & & & & & & & & & & & & & & & 61 & MT \\
\hline & & 38 & & & & & & 1 & 4 & & & & 2 & & & & 1 & & & 1 & & & & & & 98 & $\mathrm{nc}$ \\
\hline & & & & & & & & & & & & & & & & & & & & & & & & & & $4]$ & ND \\
\hline & & & & 4 & & & & & & & & & & & & & & & 1 & & & & 1 & & & 18 & $\mathrm{NE}$ \\
\hline & & & & & 3 & & & & & & & & & & & & & & & & & & 1 & & & 28 & $\mathrm{NH}$ \\
\hline & & & & & & 80 & & 7 & 19 & & & & 11 & & & & & & & & & & & & & \begin{tabular}{|l|l|}
311 \\
\end{tabular} & $\mathrm{NH}$ \\
\hline & & & & & & & 4 & 1 & & & & & & & & & & & & & & & & & & 9 & $\mathrm{NM}$ \\
\hline & & & & & & & & 45 & 1 & & & & & & & & & 1 & & & & & & & & 63 & $\mathbf{N} \mathbf{V}$ \\
\hline & & 1 & & & & 3 & & 22 & 141 & 1 & & & $t$ & & & & & 1 & & 3 & & 1 & & & 1 & 576 & $\mathrm{NY}$ \\
\hline & & 1 & & & & 4 & & 1 & 1 & 105 & & & 1 & & & & & & & 3 & & 1 & & & & 192 & $\mathrm{ot}$ \\
\hline & & & & & & & & 3 & & & 22 & & & & & & & 1 & & & & & & & & 61 & OK \\
\hline & & & & & & & & 3 & & & & 50 & & & & & & & & & & & & & & 70 & $\mathrm{OR}$ \\
\hline & & & & & & 2 & & 5 & 4 & 2 & & & 98 & & & & & & & 1 & & & & & & 248 & $\mathrm{PA}$ \\
\hline & & & & & & & & & 1 & & & & & 6 & & & & & & & & & & & & \begin{tabular}{|l|l|}
24 & \\
\end{tabular} & $\mathrm{RI}$ \\
\hline & & 1 & & & & & & & & & & & & & 9 & & & & & & & & & & & 30 & $8 c$ \\
\hline & & & & & & & & & & & & & & & & 4 & & & & & & & & & & 7 & $\$$ \\
\hline & & & & & & 1 & & 5 & 1 & & & & & & & & 33 & & 1 & & & & & & & $8 !$ & $\mathrm{TN}$ \\
\hline & & & & & & 2 & 1 & 26 & 3 & 1 & 3 & 2 & 1 & & & & & 139 & 4 & 1 & & 2 & 1 & & \begin{tabular}{l|l|}
3 \\
\end{tabular} & 586 & $\mathrm{Dx}$ \\
\hline & & & & & & & & 8 & & & & & & & & & & & \begin{tabular}{|l|}
32 \\
\end{tabular} & & & & & & & 70 & 4 \\
\hline & & & & & & 2 & & 2 & 4 & & & & & & & & 1 & & & 56 & & 2 & & & 1 & 154 & $\mathrm{VA}$ \\
\hline & & & & & & & & & 1 & & & & & & & & & & & & 4 & & & & -1 & 11 & $\sqrt{7}$ \\
\hline & & & & & & & & 1 & & & & 1 & & & & & & & & & & 68 & & & 1 & 131 & $\mathrm{WA}$ \\
\hline & & & & & & 1 & & & & & & & & & & & & & & & & & 52 & & & \begin{tabular}{|l|l|}
72 \\
\end{tabular} & $w$ \\
\hline & & & & & & & & 2 & & & & & 1 & & & & & & & & & & & 3 & & 8 & $\mathrm{~W} V$ \\
\hline & & & & & & & & & & & & & & & & & & & & & & & & & 3 & 9 & wr \\
\hline 4 & 6 & 46 & 0 & 7 & 3 & 111 & 7 & 217 & 226 & 112 & 27 & 54 & 124 & 7 & 10 & 4 & 39 & \begin{tabular}{|l|l|}
147 \\
\end{tabular} & 52 & \begin{tabular}{|l|}
74 \\
\end{tabular} & 4 & 79 & 57 & 3 & 15 & 6530 & Wota \\
\hline
\end{tabular}


Table 4 presents overall figures indicating the importance of in-state incorporations. The table displays the total number and percentage of firms incorporated in their home state-among all firms, firms that went public during 1991-1995 and during 1996-2000, Fortune 500 firms, and Fortune 100 firms. The table indicates that there is a substantial percentage of instate incorporation in all groups. Roughly $33 \%$ of all public companies incorporate in their home state. The fraction of in-state incorporations is smaller — but still substantial - for firms that went public in the 1990s and for large firms. ${ }^{44}$

\section{TABLE 4. TOTAL IN-STATE AND OUT-OF-STATE INCORPORATIONS}

\begin{tabular}{|c|c|c|c|c|c|}
\hline & \multicolumn{2}{|c|}{$\begin{array}{l}\text { Ma-State } \\
\text { Incorporations }\end{array}$} & \multicolumn{2}{|c|}{$\begin{array}{l}\text { Out-of-State } \\
\text { Ineorporations }\end{array}$} & \multirow{2}{*}{$\begin{array}{l}\text { Tolal Number } \\
\text { meorperagions }\end{array}$} \\
\hline & Sumber & $\begin{array}{l}\text { Percentage of } \\
\text {-Total } \\
\text { Incorporations }\end{array}$ & Number & $\begin{array}{l}\text { Percentage of } \\
\text { Total } \\
\text { Ihicoiporations }\end{array}$ & \\
\hline All lims & 2137 & $32.7 \%$ & 4393 & $67.3 \%$ & 6530 \\
\hline $\begin{array}{l}\text { Went Publle } \\
\text { Pre-1991 }\end{array}$ & 1213 & $37.3 \%$ & 2036 & $62.7 \%$ & 3249 \\
\hline $\begin{array}{l}\text { Weat Public } \\
1991 \text { - } 1995\end{array}$ & 417 & $32.8 \%$ & 854 & $67.2 \%$ & 1271 \\
\hline $\begin{array}{l}\text { Went Piblic } \\
1996-2000\end{array}$ & 507 & $25.2 \%$ & 1503 & $74.8 \%$ & 2010 \\
\hline Tompune 506 & 110 & $29.7 \%$ & 260 & $70.3 \%$ & 370 \\
\hline Fortune 100 & 18 & $25.3 \%$ & 53 & $74.7 \%$ & 71 \\
\hline
\end{tabular}

\section{Possible Sources}

The pattern documented above indicates that firms' incorporation choices are characterized by substantial home-state bias in favor of

44. In a fortheoming article, Robert Daines presents evidence that reinforces the findings discussed in this Section concerning the presence of a strong home-state bias in incorporation decisions. See Robert Daines, The Incorporation Choices of IPO Firms, 77 N.Y.U. L. REv. (forthcoming Dec. 2002). Studying a sample of IPOs between 1978 and 2000, Daines finds that, at the time of the IPO, firms largely chose to incorporate either in Delaware or in their home state. The results of his study, which is based on IPO-date data, thus complement the results of the study on which we build, Bebchuk \& Cohen, supra note 8 , which is based on the stock of all firms existing at the end of 1999. 
incorporating in the state of headquarters. What explains the preference given by firms to incorporating in their home state?

One possible factor that might contribute to a home-state bias is firms' desire to avoid the extra costs that might be involved in incorporating outside their home state. Incorporation in Delaware involves a franchise tax that is nonnegligible, though not substantial for most publicly traded firms. Perhaps more importantly, incorporating out-of-state might involve some additional transaction costs resulting from the need to retain additional law firms or to conduct legal business at a distance.$^{45}$ Because the extra costs of going out-of-state are unlikely to rise proportionately with firm size, this story is consistent with the fact that larger firms display weaker tendencies to incorporate in-state. ${ }^{46}$ Note that, because these extra costs are likely to be trivial for firms that are very large, and because home-state bias is still present to some extent for Fortune 500 and Fortune 100 firms, the extracost account cannot provide a full explanation for the observed home-state bias.

Another factor that might lead some firms to give preference to in-state incorporation is the hope of getting favorable treatment. Although a state should treat all firms incorporated in it in the same way regardless of where they are located, a firm located in a state-especially a large firm located in a small state-might hope that, should it incorporate in the state, its stature and clout would lead judges or other public officials to give it favorable treatment with respect to some corporate law issues that might subsequently arise. The power of political clout in a firm's home state has been reflected in the ability of some local firms confronting takeover threats to get antitakeover legislation enacted to aid them in their antitakeover efforts. ${ }^{47}$ Similarly, a firm located in a state might expect that, if it displays "loyal citizenship" by incorporating in the state, it would increase its chances of getting favorable treatment from public officials on issues unrelated to corporate law that might arise in the firm's dealings with the state.

The study by Alma Cohen and one of us finds evidence consistent with the above role of "local favoritism" considerations. ${ }^{48}$ This study finds that

45. See Douglas J. Cumming \& Jeffrey G. MacIntosh, The Rationales Underlying Reincorporation and Implications for Canadian Corporations (July 26, 2000), at http://papers.ssrn.com/sol3/papers.cfm?abstract id=218391 (reporting survey results indicating that the costs associated with incorporation play a role in the decision of Canadian companies to incorporate outside their jurisdiction).

46. See Bebchuk \& Cohen, supra note 8, at 12-13 (finding that small firm size significantly increases the likelihood of remaining in-state and interpreting this finding as consistent with the influence of transaction costs).

47. See Henry N. Butler, Corporation-Specific Anti-Takeover Statutes and the Market for Corporate Charters, 1988 WIS. L. REV. 365; Roberta Romano, The Political Economy of Takeover Statutes, 73 VA. L. REV. 111 (1987).

48. See Bebchuk \& Cohen, supra note 8 , at 13 . The possible significance of local favoritism is also noted by Fisch, supra note 15, at 1092-93. 
large firms located in a small state are more likely to remain in-state than are similarly sized firms in a large state. Location in a small state makes it more likely for a large firm to benefit from local favoritism; as a big fish in a small pond, such a firm might have substantial clout.

Yet another factor that might pull some firms in the direction of in-state incorporation is that of agency costs in the market for legal services. Recent work by John Coates has forcefully pointed out that agency problems between lawyers and owner-managers might shape choices made at the IPO stage. ${ }^{49}$ In particular, he has shown how the identity and location of the IPO law firm substantially affect the antitakeover charter provisions chosen by firms going public. Similarly, the identity of the law firm involved in a firm's IPO and the firm's subsequent corporate governance-and, in particular, whether the law firm is based in the company's state of location or elsewhere-might significantly affect the choice of incorporation state.

An in-state law firm might be inclined to keep the company in-state because such in-state incorporation would enable the law firm to handle fully the company's corporate affairs, avoiding the inconvenience and feesharing involved in having to use counsel from another state. Furthermore, in-state incorporation would provide the local law firm with an advantage over out-of-state law firms that might compete for the company's business, as the local law firm would be likely to have greater familiarity with the home state's corporate law and better connections in the state. ${ }^{50}$

In any event, a full analysis of the sources of home-state bias is beyond the scope of this Essay. What is important for our purposes is to explore the implications of the existence of home-state bias for the strength of competition in the incorporation market.

\section{Implications for Assessing Competition}

Under the conventional picture of state competition for incorporations, the incorporation choice of publicly traded firms is regarded as a "standalone" choice, a "pure" choice of a legal regime, that depends only on judgment as to which state's corporate law system would be most desirable. The corporate law rules that would best fit any given firm might depend on

49. See John C. Coates IV, Explaining Variation in Takeover Defenses: Blame the Lawyers, 89 CAL. L. REV. 1301 (2001).

50. For a discussion of the incentives of local counsel to attract incorporation to their state, see William J. Carney, The Production of Corporate Law, 71 S. CAL. L. REV. 715, 722-28 (1998). Cf. Larry E. Ribstein, Delaware, Lawyers, and Contractual Choice of Law, 19 DEL. J. CORP. L. 999 (1994) (providing a detailed analysis of the role of lawyers in the competition among states to supply noncorporate law). Daines, supra note 44 , provides empirical evidence that firms whose law firm at the time of the IPO had a more national practice were more likely to incorporate outof-state. Bebchuk and Cohen find that firms located in the Northeast, which they conjecture are more likely to use New York City lawyers engaged in national practice, are more likely to incorporate out-of-state. Bebchuk \& Cohen, supra note 8. 
various features of the firm, its shareholders, or its managers, but there is no good reason to expect them to depend on the particular location of the firm's headquarters. Under the conventional view, therefore, all states are viewed as "selling" their corporate law system to all publicly traded firms, and not especially to the firms located within their boundaries.

This view-that all states are potential competitors for each companyis an important element of the vigorous competition picture. If this element were indeed present, we could still expect some states to be more successful than others in attracting a given type of firm, but we would not expect a state to be more successful in attracting local firms than out-of-state firms. As shown above, however, this is what in fact takes place.

Thus, the existing situation should not be understood as one in which fifty-one "sellers" of corporate law rules compete in a "national" market over any given firm. Rather, the existing situation might be better understood as one in which there are fifty-one local markets, with the firms located in each of them making a choice between incorporating in their home state or out of it. Furthermore, as we shall see before too long, the vast majority of firms that opt for out-of-state incorporation go to Delaware, and firms in each local market are currently making a choice that is effectively between incorporating in their home state or in Delaware.

The presence of home-state bias is quite important for assessing the incentives facing Delaware and its potential competitors. There is no reason to think that all of the firms incorporated in-state are exactly on the fencethat is, that they prefer to incorporate in their home state rather than in Delaware by only a very small margin. Some of the companies currently incorporated in their home state might be close to the margin in the sense that even slight improvements in the corporate law of other states would make them change the venue of their incorporation. The home bias of other companies, however, might be so strong that even significant improvements in the corporate law offered by other jurisdictions would be insufficient to make them incorporate outside their home state.

The above implies that, in assessing Delaware's competitive situation, it would be important not only to look at the division of the general incorporations market, but also to look at the submarket made by out-ofstate incorporations. In any study of imperfect competition, defining the relevant market for examination is a necessary first step in assessing market power. ${ }^{51}$ A key factor in defining the relevant market is the degree of substitution across products. ${ }^{52}$ The presence of a significant home-state bias

51. See, e.g., HERBERT Hovenkamp, FEDERAL ANTITRUST POLICY: THE LAW OF COMPETITION AND ITS PRACTICE $82-83$ (2d ed. 1999) (stating that in antitrust cases that require proof of market power, the court will first determine what is the relevant market).

52. See United States v. Microsoft Corp., 253 F.3d 34, 52 (D.C. Cir. 2001) (stating that "the relevant market must include all products reasonably interchangeable by consumers for the same 
effect suggests that, at least for some public companies, the corporate laws of their home state and of other states are not perfectly interchangeable. Hence, it is important to examine Delaware's market power with respect to out-of-state incorporations. Examining this market can provide us with a sense of the extent to which states competing with Delaware over the outof-state incorporation business have made inroads into this market.

Furthermore, examination of the division of the out-of-state incorporations market is necessary for assessing the possibility of mounting a challenge to Delaware's dominance. Consider a state that is contemplating an all-out effort to unseat Delaware as the dominant provider of corporate law. To lure companies already incorporated outside their home state, i.e., companies that do not need to overcome their home-state bias, it would be sufficient for the rival state to offer a product that is only slightly better overall than Delaware's. Slightly improving upon Delaware's law, however, might be insufficient to attract companies still incorporated in their home state to the extent that these companies have a significant preference for incorporating in their home state. ${ }^{53}$

\section{Delaware's Dominant Position}

\section{Delaware's Monopolistic Position}

Having concluded that it is useful to consider not only Delaware's fraction of the national incorporation market as a whole but also its fraction of out-of-state incorporations, we now turn to examine the latter. As mentioned earlier, the common picture of Delaware's market share, based on data pertaining to the overall U.S. incorporation market, is roughly fifty percent. ${ }^{54}$ Though this market share is large, it is also indicative of substantial competition by other states. ${ }^{55}$ In the previous Section, we have

purposes"); 1992 Horizontal Merger Guidelines, 57 Fed. Reg. 41,552, 41,554 (Sept. 10, 1992) (noting the importance of the elasticity of demand in defining the relevant market); Daniel L. Rubinfeld, Market Definition with Differentiated Products: The Post/Nabisco Cereal Merger, 68 ANTITRUST L.J. 163, 165-66 (2000). The degree of supply substitution might also be relevant in defining the relevant market. See Jonathan B. Baker, The Problem with Baker Hughes and Syufy: On the Role of Entry in Merger Analysis, 65 ANTITRUST L.J. 353 (1997) (reviewing the role of potential entry and supply substitution in antitrust analysis). As we explain in the next Part, however, the market for incorporation is characterized by barriers to entry that impede the entry of new "suppliers" of corporate law.

53. Also, as we show below, focusing on the market for out-of-state incorporation enables us to identify incorporation trends and predict an increase in Delaware's share of the overall market. See infra text accompanying notes 59-60.

54. Under the study upon which we rely, which excludes financial firms, Delaware's share of the overall incorporation market is approximately $58 \%$. See supra Section III.A.

55. In antitrust cases, for instance, a market share of $50 \%$ would be insufficient to infer monopoly power. See United States v. Paramount Pictures, Inc., 334 U.S. 131 (1948) (suggesting that a $70 \%$ market share is sufficient to establish market power); HOVENKAMP, supra note 51, at 
suggested that the presence of a home-bias effect makes it important to examine Delaware's share not only of all U.S. incorporations, but also of the segment of out-of-state incorporations. As we show in this Section, Delaware's share of out-of-state incorporations is substantially larger-and the share of states other than Delaware is substantially smaller-than the respective shares among incorporations in general.

Table 5 presents the distribution of companies by state of incorporation, but only for public companies incorporated outside their home state. This table presents data for all public companies, for Fortune 500 companies, and for all companies that went public between 1996 and 2000.

270 (finding that courts will be reluctant to find monopoly power when defendants' market share is lower than $70 \%$ ). 
TABLE 5. THE DIVISION OF THE MARKET FOR OUT-OF-STATE INCORPORATIONS

\begin{tabular}{|c|c|c|c|c|c|c|c|c|}
\hline \multicolumn{3}{|c|}{$\begin{array}{l}\text { All Publicly Traded } \\
\text { Nonfinancial Companies }\end{array}$} & \multicolumn{3}{|c|}{$\begin{array}{l}\text { Fortune } 500 \\
\text { Financial Companies }\end{array}$} & \multicolumn{3}{|c|}{$\begin{array}{l}\text { Nonfinancial Companies } \\
\text { That Went Public During } \\
1996-2000\end{array}$} \\
\hline State & $\begin{array}{l}\text { Number } \\
\text { of Firms }\end{array}$ & Percentage & State & $\begin{array}{l}\text { Number } \\
\text { of Firms }\end{array}$ & Percentage & State & $\begin{array}{l}\text { Number } \\
\text { of Firms }\end{array}$ & Percentage \\
\hline Total & 4393 & $100 \%$ & Total & 260 & $100 \%$ & Total & 1503 & $100 \%$ \\
\hline $\mathrm{DE}$ & 3744 & $85.23 \%$ & $\mathrm{DE}$ & 216 & $83.08 \%$ & $\mathrm{DE}$ & 1356 & $90.22 \%$ \\
\hline NV & 172 & $3.92 \%$ & $N Y$ & 9 & $3.46 \%$ & $\mathrm{NV}$ & 61 & $4.06 \%$ \\
\hline $\mathrm{NY}$ & 85 & $1.93 \%$ & $\mathrm{NV}$ & 5 & $1.92 \%$ & $\mathrm{CO}$ & 18 & $1.20 \%$ \\
\hline $\mathrm{CO}$ & 58 & $1.32 \%$ & $\mathrm{MD}$ & 4 & $1.54 \%$ & $\mathrm{FL}$ & 11 & $0.73 \%$ \\
\hline NI & 31 & $0.71 \%$ & $\mathrm{NJ}$ & 4 & $1.54 \%$ & $\mathrm{MD}$ & 6 & $0.40 \%$ \\
\hline $\mathrm{MD}$ & 29 & $0.66 \%$ & IN & 3 & $1.15 \%$ & UT & 6 & $0.40 \%$ \\
\hline$F L$ & 28 & $0.64 \%$ & $\mathrm{KS}$ & 3 & $1.15 \%$ & $\mathrm{NY}$ & 5 & $0.33 \%$ \\
\hline $\mathrm{PA}$ & 26 & $0.59 \%$ & $\mathrm{PA}$ & 3 & $1.15 \%$ & PA & 4 & $0.27 \%$ \\
\hline $\mathrm{MN}$ & 20 & $0.46 \%$ & $\mathrm{NC}$ & 2 & $0.77 \%$ & $\mathrm{TX}$ & 4 & $0.27 \%$ \\
\hline UT & 20 & $0.46 \%$ & $\mathrm{OH}$ & 2 & $0.77 \%$ & $\mathrm{GA}$ & 3 & $0.20 \%$ \\
\hline VA & 18 & $0.41 \%$ & VA & 2 & $0.77 \%$ & $\mathrm{KS}$ & 3 & $0.20 \%$ \\
\hline $\mathrm{GA}$ & 12 & $0.27 \%$ & FL & 1 & $0.38 \%$ & $\mathrm{MN}$ & 3 & $0.20 \%$ \\
\hline WY & 12 & $0.27 \%$ & $\mathrm{GA}$ & 1 & $0.38 \%$ & $\mathrm{NC}$ & 3 & $0.20 \%$ \\
\hline IN & 11 & $0.25 \%$ & HI & 1 & $0.38 \%$ & WA & 3 & $0.20 \%$ \\
\hline WA & 11 & $0.25 \%$ & KY & 1 & $0.38 \%$ & $\mathrm{IN}$ & 2 & $0.13 \%$ \\
\hline $\mathrm{CA}$ & 10 & $0.23 \%$ & $\mathrm{MA}$ & 1 & $0.38 \%$ & NJ & 2 & $0.13 \%$ \\
\hline $\mathrm{MA}$ & 10 & $0.23 \%$ & $\mathrm{TN}$ & 1 & $0.38 \%$ & OR & 2 & $0.13 \%$ \\
\hline $\mathrm{MO}$ & 10 & $0.23 \%$ & UT & 1 & $0.38 \%$ & TN & 2 & $0.13 \%$ \\
\hline $\mathrm{KS}$ & 8 & $0.18 \%$ & & & & $\mathrm{CA}$ & 1 & $0.07 \%$ \\
\hline $\mathrm{NC}$ & 8 & $0.18 \%$ & & & & IL & 1 & $0.07 \%$ \\
\hline $\mathrm{TX}$ & 8 & $0.18 \%$ & 3 & & & LA & 1 & $0.07 \%$ \\
\hline $\mathrm{OH}$ & 7 & $0.16 \%$ & & & & MI & 1 & $0.07 \%$ \\
\hline TN & 6 & $0.14 \%$ & & & & $\mathrm{MO}$ & 1 & $0.07 \%$ \\
\hline Other & 49 & $1.12 \%$ & & & & Other & 4 & $0.27 \%$ \\
\hline
\end{tabular}

Table 5 shows that Delaware's share of the out-of-state incorporation market is significantly larger than its share of the overall incorporation market. While $58 \%$ of U.S. public companies are incorporated in Delaware, $85 \%$ of the companies that choose to incorporate outside their home state incorporate in Delaware. Likewise, $59 \%$ of Fortune 500 companies are incorporated in Delaware, whereas $83 \%$ of Fortune 500 companies incorporating outside their home state are incorporated in Delaware. This 
degree of market concentration is considered to be very large. ${ }^{56}$ Indeed, the value of the Herfindahl index, a tool commonly used by economists to measure market concentration, in the market for out-of-state incorporation for all public companies is 3435 , and, with respect to Fortune 500 companies, the value of this index is $3638 .{ }^{57}$ To put these numbers in perspective, note that, under the Department of Justice 1992 Horizontal Merger Guidelines, markets where the value of the postmerger Herfindahl index is above 1800 are regarded as highly concentrated. ${ }^{58}$

\section{Current Trends}

To assess the strength of Delaware's dominance, it would be worthwhile to examine not only Delaware's current share of total incorporations and total out-of-state incorporations but also to consider how these shares have been evolving over time. To identify recent trends in the out-of-state incorporation market, Table 6 shows Delaware's fraction of companies going public over three different periods-prior to 1991, between 1991 and 1995, and between 1996 and 2000.

TABLE 6. DELAWARE'S SHARE OF OUT-OF-STATE INCORPORATIONS

\begin{tabular}{|l|l|c|c|c|}
\hline \multicolumn{2}{|c|}{} & $\begin{array}{c}\text { Fraction of } \\
\text { Firms Going } \\
\text { Out-of-State }\end{array}$ & $\begin{array}{c}\text { Delaware's Fraction } \\
\text { of Out-of-State } \\
\text { Incorporations }\end{array}$ & $\begin{array}{c}\text { Delaware's } \\
\text { Fraction of All } \\
\text { Incorporations }\end{array}$ \\
\hline $\begin{array}{l}\text { Period in } \\
\text { Which Firms } \\
\text { Went Public }\end{array}$ & Pre-1991 & $62.6 \%$ & $80.4 \%$ & $50.4 \%$ \\
\cline { 2 - 5 } & $1991-1995$ & $67.2 \%$ & $87.9 \%$ & $59.1 \%$ \\
\hline
\end{tabular}

Table 6 shows that Delaware has a dominant share of the market for out-of-state incorporations and that this dominance has been increasing in the last decade. Delaware's share of the overall U.S. incorporation market also has been growing in recent years. ${ }^{59}$ This increase in Delaware's market share has been viewed as indicating the growing recognition of the

56. See HOVENKAMP, supra note 51 , at 270.

57. For a formulation of this index, see JEAN TIROLE, THE THEORY OF INDUSTRIAL ORGANIZATION 221-22 (1988).

58. See 1992 Horizontal Merger Guidelines, 57 Fed. Reg. 41,552, 41,558 (Sept. 10, 1992); HOVENKAMP, supra note 51, at 516-17.

59. Table 2 indicates a growth in Delaware's share of the overall incorporation market. While $58 \%$ of public companies are incorporated in Delaware, $68 \%$ of companies that went public between the years 1996 and 2000 have chosen to incorporate in Delaware. See also Daines, supra note 39 , at 537-38 tbl. 2 (reporting an increase in Delaware's share of the overall incorporation market from $44.3 \%$ in 1981 to $55.8 \%$ in 1996 ). 
superiority of Delaware law. ${ }^{60}$ The evidence presented above in Tables 4 and 6, however, indicates that the increase in Delaware's share is substantially due to the growing willingness of firms to incorporate out-ofstate. Table 4 shows that the home-bias effect is weaker for younger companies. While $62.7 \%$ of companies that went public before 1991 incorporated outside their home state, $74.8 \%$ of the companies that went public between the years 1996 and 2000 incorporated outside their home state. This pattern suggests that the recent increase in Delaware's overall market share might be the result of the decline in the magnitude of the home-bias effect rather than an increase in the attractiveness of Delaware corporate law.

More importantly, the pattern emerging from Table 4 suggests that Delaware's current large fraction of total incorporations can be expected to increase further in the future. Assuming that firms going public in the future continue to display the weaker tendency to incorporate in-state that firms going public recently have been displaying, Delaware's total market share can be expected to increase significantly before too long.

\section{The Absence of Challenges by Other States}

As we have seen, Delaware captures a great majority of out-of-state incorporations. Furthermore, as we shall explain in the next Section, Delaware derives large profits from its market share. Markets in which supracompetitive profits are made often attract effort by rivals to capture some or all of these profits. Thus, one might think that the presence of these supracompetitive profits would induce other states to make efforts to capture some of Delaware's incorporations and profits. However, as Kahan and Kamar document in a detailed and compelling way, other states are not making significant active efforts to attract out-of-state incorporations. ${ }^{61}$

In particular, states have made no effort to develop the infrastructure necessary for attracting out-of-state incorporations. The corporate law system offered by Delaware includes not only the substantive corporate law rules, but also the institutional infrastructure provided by Delaware for applying and implementing these rules. Among other things, this infrastructure includes Delaware's specialized corporate court, the chancery court, with its expert judiciary and ability to resolve quickly complex business disputes, as well as the surrounding infrastructure of professionals and providers of incorporation and legal services. ${ }^{62}$ The presence of this

60. See id.

61. See Kahan \& Kamar, supra note 17 (manuscript at 30-65).

62. See, e.g., Klausner, supra note 6, at $845-46$; William H. Rehnquist, The Prominence of the Delaware Court of Chancery in the State-Federal Joint Venture of Providing Justice, 48 BUS. LAW. 351, 354 (1992). 
institutional infrastructure is an important component of the quality of the system offered by Delaware. Thus, a state wishing to lure out-of-state incorporations will be expected to put the necessary resources into developing such institutional infrastructure. ${ }^{63}$ Thus far, however, no state other than Delaware has made a serious effort to design its court system in a way that would be attractive to corporations. ${ }^{64}$

Indeed, states have not even structured their incorporation taxes and fees in a way that would provide them with meaningful benefits if they were to attract many out-of-state incorporations. Under the conventional premise of active competition among states, states are motivated to attract incorporations by their interest in maximizing their franchise tax revenues. ${ }^{65}$ This premise implies that states capture additional franchise tax revenues when companies choose them as their state of incorporation. Indeed, the dominant state, Delaware, derives a significant fraction of its total revenues from incorporation-related taxes. ${ }^{66}$

As Kahan and Kamar document, however, Delaware is the only state that structures its tax system to derive substantial additional revenues from incorporations. ${ }^{67}$ All other states employ one of two taxing methods: (i) imposing taxes on corporations only to the extent to which they conduct business within the state, regardless of their state of incorporation; or (ii) imposing only trivial fees on corporations incorporated in the state. This prevalent structure of the tax system therefore suggests that states are not attempting to make any profits from increasing the number of out-of-state incorporations.

It might be argued that the failure to create a significant scheme of incorporation-related taxes cannot be explained by the absence of competition for out-of-state incorporations. After all, the argument goes, as long as some corporations, whether out-of-state or local, incorporate in a given state, the state would have an incentive to increase its incorporation revenues by charging a tax for its incorporation services. This argument, however, is unpersuasive.

63. On the effect of the need to invest in infrastructure on the likelihood of successful entry into the market for incorporations, see discussion infra Section IV.B.

64. See Kahan \& Kamar, supra note 17 (manuscript at 42-53).

65. See, e.g., Cary, supra note 7, at 668-69; Romano, supra note 27, at 2388 ("In the corporate law setting, the benefit is financial: States collect franchise tax revenues from locally incorporated firms."); Winter, State Law, supra note 6, at 255. But see Loewenstein, supra note 35, at 501-02 (arguing that state legislators are motivated to produce corporate law primarily by public policy concerns, rather than by a desire to attract incorporations in order to maximize tax revenues).

66. In 2001, franchise tax revenues constituted roughly $27 \%$ of Delaware's total tax revenues. See U.S. CENSUS BUREAU, supra note 13 (documenting that revenues from franchise taxes were $\$ 600,593,000$ while total tax revenues were $\$ 2,174,440,000)$. Delaware obtained an additional $3 \%$ of its tax revenues from documentary and stock-transfer taxes, which are at least partly attributable to the incorporation business. Id.

67. See Kahan \& Kamar, supra note 15, at 1218-22. 
While states do not charge local companies directly and separately for incorporation services, states do derive substantial revenues from such companies through income and other taxes. Indeed, incorporation services are not unique in this respect; states also do not charge local companies directly and separately for many other services and benefits. Administrative considerations might make it more efficient to charge local companies using, say, income and property taxes, rather than numerous separate charges and fees. In short, local companies pay for incorporation services, so to speak, through the other taxes they are already paying to their state. In contrast, when out-of-state firms that have no other link to a state incorporate in it, the only way for the state to benefit from these firms would be to charge them incorporation taxes and fees.

If states are not making any direct profits from incorporations, it might be asked why they nonetheless offer corporate laws. One main reason is that states might offer such rules as a service to their local firms. States, after all, offer various services to local firms without charging them separately for each service. The fact that all states, regardless of the structure of their franchise tax system, supply corporate codes suggests that states do have some incentives to engage in the production of corporate laws. Out-of-state incorporation involves transaction costs that local corporations might be reluctant to bear, and local lawyers have an interest in having their clients incorporate in their home state. These reasons might be sufficient to induce states to offer their local corporations the option to incorporate at a nominal fee.

For our purposes, however, the important point is that the manner in which states have chosen to design their franchise tax systems indicates that states other than Delaware are not aiming at, and are not harboring hopes of, making profits from attracting a significant number of incorporations. Why is this the case? One possible explanation that is worth considering up-front is that, while it indeed captures a significant amount of revenues, Delaware makes no supracompetitive profits, thus leaving other states with no incentives to challenge its lead. As the next Section will show, however, Delaware does make such profits.

\section{E. Monopoly Profits}

That Delaware enjoys such a dominant position does not imply by itself that Delaware does not face-and is not influenced very much by-a very strong competitive threat. When a monopolist operates in a market that is perfectly contestable, with no barriers to entry whatsoever, the mere threat of entry and replacement is very powerful and would prevent a monopolist 
from making any supracompetitive returns. ${ }^{68}$ In such a perfectly contestable market, given that the monopolist is not making such profits, rivals would have no reason to enter, but their potential competition would be very much at work.

Delaware's tax revenues constitute a large fraction of its annual budget. In 2001 , these tax revenues amounted to $\$ 600$ million. ${ }^{69}$ In our view, the significance of these taxes can be best appreciated from a per capita perspective. Dividing the tax revenues by the number of Delaware's residents, we find that each Delaware household of four gains $\$ 3,000$ annually.

The impressive size of Delaware's incorporation-related tax revenues does not necessarily imply that Delaware captures monopoly profits. In theory, such an amount of revenue might reflect the large costs incurred by Delaware in providing the services it offers to its corporations. As Kahan and Kamar have observed, however, Delaware's franchise tax revenues represent supracompetitive returns, reflecting profit margins of several thousand percent. ${ }^{70}$ Specifically, over the past thirty-five years, Delaware has commonly devoted less than three percent of its franchise tax revenues to cover the costs of operating its incorporation business. ${ }^{71}$

Furthermore, in addition to its substantial franchise tax revenues, Delaware derives additional benefits from its incorporation business. These benefits include the fees paid by companies to local providers of services, especially lawyers and local corporate service companies. ${ }^{72}$ For example, Kahan and Kamar estimate that, for 2001, the incorporation business increased the total income derived by Delaware lawyers by $\$ 165$ million. ${ }^{73}$ These revenues, and the profits derived from them, further augment Delaware's return on its incorporation business.

68. See William J. Baumol et al., Contestable Markets and the theory of INDUSTRY STRUCTURE (1982).

69. See supra note 13.

70. See Kahan \& Kamar, supra note 15 , at 1211.

71. For example, in 1996 , Delaware's expenditures were $\$ 9.5$ million, whereas its franchise tax revenues were $\$ 350$ million. See Romano, supra note 27 , at 2429 tbl.1.

72. See John C. Coffec, Jr., The Future of Corporate Federalism: State Competition and the New Trend Toward De Facto Federal Minimum Standards, 8 CARDOzo L. REV. 759, 762 (1987); Jonathan R. Macey \& Geoffrey P. Miller, Toward an Interest-Group Theory of Delaware Corporate Law, 65 TEX. L. REV. 469, 492-93 (1987). Companies may be indirectly required to bear the cost of incorporation-related revenues by their state of incorporation. Delaware law, for example, requires all chartered firms to be represented in the state by a local registered agent. See DEL. CODE ANN. tit. 8, $\S 102(a)(2)$ (2001). This requirement generates incorporation-related revenues for these local agents and, indirectly, for Delaware itself.

73. See Kahan \& Kamar, supra note 17 (manuscript at 23). 


\section{F. What Needs To Be Explained}

In the previous Sections of this Part, we have shown that (i) Delaware has a monopoly position in the market for out-of-state incorporations, (ii) Delaware makes substantial supracompetitive returns on the business of out-of-state incorporations, and (iii) other states have not been exerting efforts to make themselves attractive for out-of-state incorporations. Why has Delaware's dominance gone unchallenged for so long?

One possible reason that needs to be considered is that Delaware's objective function is different and that other states are simply not interested in making profits from such a business. Kahan and Kamar argue that Delaware's potential competitors "are not business organizations motivated by profits" but rather "are state bureaucracies pursuing political goals and operating under political constraints that impede their ability to compete effectively in the market for incorporations. ${ }^{, 74}$ We very much agree that the magnitude of the profits made by Delaware is likely to provide little motivation for some large states such as California, where the prospect of making such profits might well be insufficient to make much of an impression. Large states are unlikely to be much moved, and are therefore unlikely to be guided in designing their corporate laws and institutional infrastructure, by this amount of money.

However, we believe that this "different objectives" explanation cannot fully account for the behavior of all small states. In our view, there are likely to be some other small states for which the amounts now made by Delaware would be quite substantial and attractive and which, if they could act to capture such profits, would indeed do so. To illustrate, South Dakota has a population slightly lower than Delaware's and a much smaller state budget; Delaware's 2001 franchise tax revenues constitute sixty-one percent of South Dakota's total revenues from taxes in $2001 .^{75}$ If South Dakota could capture Delaware's current revenues, it would be able to reduce its taxes by sixty-one percent or, alternatively, to increase state spending by such an amount. Either way, this would constitute a strong motivation indeed; for a sizable increase in state revenues (or a reduction in taxes) can provide sufficiently large payoffs to relevant political actors to influence even the decisions of state bureaucracies that act, as Kahan and Kamar stress, with political goals and under political constraints.

Another way of making this point is by noting that, like other small states, the relevant political actors in Delaware are also acting with political

74. See id. (manuscript at 8 ).

75. In 2001, South Dakota's tax revenues were approximately $\$ 977$ million, and its population was 757,000. See U.S. Census BuREaU, South Dakota STATE GovernMent TAX COLLECTIONS: 2001 (2002), at http://www.census.gov/govs/statetax/0142sdstax.html. Delaware's revenues from franchise taxes for 2001 were approximately $\$ 600$ million. See supra note 66 . 
goals and under political constraints. Thus, political goals and political constraints cannot provide sufficient explanation for why other small states are acting so differently from Delaware.

Kahan and Kamar also suggest that, even if Delaware's profits from its large number of incorporations could be sufficiently attractive to some other states, the minimal franchise tax rates used by other states imply that, even if such a state could obtain a large number of out-of-state incorporations, it would not make the kind of profits that Delaware now makes from such incorporations. ${ }^{76}$ The question, however, is why states other than Delaware use such minimal franchise tax rates. In the analysis below we will take other states' minimal franchise tax rates not as given but rather as an endogenous feature, which needs to be explained, of the existing state of affairs. We do not view the minimal tax rates used by states as making them indifferent to attracting out-of-state incorporations. Rather, we view the use of such minimal rates as itself a reflection of the fact that such states do not expect to attract a significant number of such incorporations, and thus see little reason for developing franchise tax systems that would be profitable only with a significant number of incorporations.

In sum, what needs to be explained is the difference in behavior between Delaware and other small states. Given that capturing Delaware's current profits would be attractive for other small states, why are such states not making an effort to attract out-of-state incorporations or even bothering to adopt a franchise tax system that would provide them with substantial revenues in the event that many out-of-state incorporations are attracted? The difference between Delaware and other small states is unlikely to lie in considerable differences in political goals and political constraints between Delaware's and other states' officials. Rather, the explanation developed by the next Part is that other small states behave differently because of the different profit opportunities that they face. Because of the structure of the incorporation market and Delaware's initial incumbency advantages, a challenge by such a state cannot be expected to be profitable and is thereby discouraged.

\section{THE ABSENCE OF VIGOROUS COMPETITION: EXPLANATIONS}

This Part analyzes several structural features of the market for incorporations that discourage rival states from mounting a challenge to Delaware and that can explain Delaware's secure dominance. Sections A and $\mathrm{B}$ establish the basis for the analysis by discussing the importance in this market of network externalities and institutional infrastructure,

76. See Kahan \& Kamar, supra note 17 (manuscript at 11-14). 
respectively. Section $\mathrm{C}$ explains the futility of challenges based on priceundercutting or on limited local changes. Section D discusses the difficulty facing challenges that are not supported by managers. Finally, Section $\mathrm{E}$ analyzes how Delaware's ability to respond by matching or improving upon what challengers offer, which is facilitated by the long time frame that would be required for a challenger to obtain a large market position, further discourages challenges to Delaware's dominance.

It is worth stressing that the structural features analyzed below do not absolutely rule out any future challenge to Delaware's dominance by another state. They provide Delaware with a substantial slack but not with an unlimited one. For example, if Delaware were to err by adopting rules that were sufficiently bad, a rival state might decide to challenge Delaware's dominance. We therefore view Delaware as facing a far weaker threat from other states than commonly recognized, but not as facing no threat whatsoever. For this reason, our questioning of the existence of a vigorous race leads us to refer to a "leisurely walk" and not to Delaware's "sitting still." By making a challenge unlikely to be profitable in ordinary circumstances, the structural features discussed below merely explain why a challenge has not occurred for a very long time and why, given the very small likelihood of a challenge, Delaware faces a very weak threat of a challenge by another state.

\section{A. Network Externalities}

The market for incorporations is characterized by network externalities that produce barriers to entry. Network externalities exist "where purchasers find a good more valuable as additional purchasers buy the same good." 77 According to Michael Klausner, who was the first to stress the importance of network externalities in the incorporation market, this market is characterized by both "interpretative externalities" and "legal service" externalities. $^{78}$

Interpretative externalities refer to the net present value of future judicial decisions interpreting the state's corporate law. The quality of future case law depends on the number and diversity of lawsuits brought before the courts. These factors, in turn, depend on the number of firms incorporated in the state. As long as a large number of firms remains incorporated in Delaware, its courts will likely "produce a steady stream of

77. Mark A. Lemley \& David McGowan, Legal Implications of Network Economic Effects, 86 CAL. L. REV. 479, 483 (1998); see also Michael L. Katz \& Carl Shapiro, Network Externalities, Competition, and Compatibility, 75 AM. ECON. REV. 424, 424 (1985).

78. See Klausner, supra note 6, at 843-44. 
case law that addresses cutting-edge issues in a timely fashion." decision where to incorporate will be based not only on the inherent value of corporate law offered by the competing states but also on the number of firms incorporated in each state.

Legal service externalities refer to the benefit that accrues to firms from having a large number of providers of legal services apply the state's corporate law. The larger the number of such providers, the larger will be the number of capital-market participants and their advisers that can know the rules applicable to a company without additional investment in information acquisition. Thus, the value of these benefits also increases with the number of firms incorporated in a particular state.

The presence of network externalities commonly makes competition more imperfect. Competition in markets with substantial network effects is usually for the dominant market position-i.e., competition is "for the field" rather than "within the field." "\$0 The early leader, offering the largest network benefits, will successfully attract additional consumers and have good chances of dominating the market. Moreover, once a monopoly is achieved, network effects reinforce its position and produce substantial barriers to entry. ${ }^{81}$ Since consumers switching to a new entrant will lose the network benefits offered by the dominant firm, a new entrant will successfully attract consumers only if it can quickly attain a critical mass of consumers or develop a sufficiently superior product that will compensate consumers switching to the new entrant for their loss of network benefits. ${ }^{82}$ Indeed, in the recent Microsoft case, the network effects characterizing the market for personal computer operating systems have been found to constitute a substantial entry barrier. ${ }^{83}$

79. Id. at 845; see also Marcel Kahan \& Michael Klausner, Standardization and Innovation in Corporate Contracting (or "The Economics of Boilerplate"), 83 VA. L. REV. 713 (1997). But see Lemley \& McGowan, supra note 77, at 566-76 (questioning the extent to which the market for contracts generally, and incorporations specifically, exhibits network externalities); Romano, supra note 25, at 493-507 (casting doubt on the existence of network effects in the market for corporate law and arguing that corporate law will be efficient despite the existence of these effects).

80. See United States v. Microsoft Corp., 253 F.3d 34, 49 (D.C. Cir. 2001) (citations omitted); Howard A. Shelanski \& J. Gregory Sidak, Antitrust Divestiture in Network Industries, 68 U. CHI. L. REV. 1, 5 (2001) (stating that "[c]ompetition in network markets can therefore take on a winner-take-all dynamic with competitive strategies geared towards gaining an early lead in market penetration").

81. See Michael L. Katz \& Carl Shapiro, Systems Competition and Network Effects, $8 \mathrm{~J}$. ECON. PERSP. 93, 109-13 (1994); Steven C. Salop \& R. Craig Romaine, Preserving Monopoly: Economic Analysis, Legal Standards, and Microsoft, 7 GEO. MASON L. REV. 617, 620-21 (1999).

82. See Shelanski \& Sidak, supra note 80 , at 9.

83. See Microsoft, 253 F.3d at 55 (discussing the "applications barrier to entry" that arises because "(1) most consumers prefer operating systems for which a large number of applications have already been written; and (2) most developers prefer to write for operating systems that already have a substantial consumer base"). 
Delaware, with a market share of approximately eighty-five percent of out-of-state incorporations, enjoys a clear incumbency advantage over other states. In order to challenge Delaware successfully, other states must either attract a sufficient mass of incorporations that would produce comparable network benefits or offer corporate laws that would be substantively far superior to Delaware's to compensate for the loss of network benefits offered by Delaware. As our analysis below will show, either route is expected to be rather difficult for potential rivals.

\section{B. Investment in Institutional Infrastructure}

In addition to the network benefits associated with incorporating in Delaware, there is another type of benefit Delaware offers-the quality of its legal infrastructure. As explained earlier, ${ }^{84}$ a system of corporate law includes not only the substantive rules of corporate law, but also the institutional infrastructure provided by the state for applying and implementing these rules. This infrastructure should also be viewed as an aspect of the product offered by Delaware.

To offer network benefits, a challenger would have to attract many incorporations. To offer an institutional infrastructure, the challenger would first have to make some necessary investments. For one thing, it would have to set up a specialized, expert business court. Developing such legal infrastructure would be costly and time-consuming. ${ }^{85}$ The costs would come not only from out-of-pocket expenditures but, more importantly, from the institutional resources, attention, and determination needed for adapting the state's judicial system to include a specialized court and for the state's legislature to have a mechanism for close and immediate attention to legislative changes if they become needed.

Note that such an up-front investment will become sunk: If the state fails to grab a significant market share from Delaware, the resources it invested in developing this infrastructure will be of no alternative use. ${ }^{86} \mathrm{Up}$ front sunk investments are important for our analysis, because they are generally recognized to produce barriers to entry. ${ }^{87}$ In our context, a state would be willing to make the necessary up-front investment only if it can expect to make a sufficient return on it. As we shall show below, the need

84. See supra note 62 and accompanying text.

85. On the critical importance of time in this context, see our discussion of Delaware's likely response to a challenge by a rival state infra Section IV.E.

86. See Bebchuk \& Ferrell, New Approach, supra note 7, at 154-55 (pointing to the sunk costs involved in mounting a challenge to Delaware).

87. See generally TIROLE, supra note 57 , at 307-11 (discussing the barriers to entry created by the need to bear fixed and sunk costs). 
of the state to recoup the up-front investment in infrastructure intensifies the barrier to entry produced by Delaware's network benefits.

Although the literature has focused on the institutional infrastructure offered by the state itself, especially its court system, there is another important element that has not received notice, namely, the presence of an appropriate system of legal and other professional service firms. For one thing, Delaware has law firms with established practices and expertise to serve smoothly as a liaison between out-of-state firms and their advisers and Delaware's court system. Such a system does not exist at present in other small states whose chances of becoming a challenger we are assessing.

Again, the presence of such legal service providers requires up-front investments, but this time by private actors. For North Dakota to offer an infrastructure similar to Delaware's, North Dakota law firms would have to undertake certain expansions and hiring. These investments, again, would be made only if the law firms could expect to recoup them. Although, for simplicity, we will below focus on the absence of sufficient incentives for states to make needed up-front investments, our discussion will also largely apply to the needed investments by private actors.

\section{The Futility of Price-Based and Local Challenges}

We have seen that Delaware offers a multidimensional product that includes, in addition to certain legal rules, network benefits and the value of a sophisticated infrastructure. As we now turn to show, this nature of the Delaware product by itself indicates that rivals will not be able to make major inroads into the market by offering the same rules and undercutting Delaware's prices, or by offering rules that marginally improve on Delaware's rules.

\section{The Futility of Challenges Based on Undercutting Prices}

The presence of network externalities and the value of institutional infrastructure imply that it would be futile for a state to seek to oust Delaware from its dominant position by competing mainly on price. In fact, Delaware has been able to maintain its dominance even though incorporation in states other than Delaware involves only negligible costs in terms of franchise taxes and fees. ${ }^{88}$

88. The assumption that competition is not about prices is implicit in much of the existing literature. See, e.g., EASTERBROOK \& FISCHEL, supra note 6, at 6 (noting that states compete to offer "beneficial sets of legal rules"); ROMANO, supra note 5, at 15 (observing that under both Cary's and Winter's classic positions, the goal of maximizing revenues leads state corporation 
It is natural to start considering competition in terms of price competition. In some markets, rivals can hope to capture a substantial market share or even a dominant position by undercutting prevailing prices. In theory, if another state were to offer the same corporate law product as the one Delaware offers but at a lower price, then it would become more attractive than Delaware for out-of-state incorporations. Note, however, that this proposition necessarily holds only if the good the rival state offers is identical in quality to the good Delaware offers. This, in turn, implies that the rival state cannot offer merely the same rules as Delaware, as these rules constitute only one element of Delaware's corporate law product.

Assume that a rival state simply adopts all of Delaware's corporate code and past precedents concerning corporate issues but does not offer a legal infrastructure of similar value to Delaware's. Assume further that this state offers incorporation at a lower price than Delaware's. This strategy still would be unlikely to attract many out-of-state incorporations. Not offering a legal infrastructure and (at least not initially) network benefits, the overall quality of the product this state would offer would be lower than the quality of Delaware's competing product. Charging lower incorporation taxes and fees would be insufficient to overcome this quality deficiency and attract many out-of-state incorporations.

At first sight, it might be argued that a rival state could always attract incorporations to an inferior product by undercutting its franchise taxes by an amount sufficient to compensate companies for the loss of the benefits associated with Delaware's network and infrastructure. In theory, buyers should be willing to purchase a product of somewhat inferior quality provided they are given a sufficient reduction in price. In the incorporation market, however, the necessary reduction would likely result in a "negative" price, meaning that the considered rival state would need to offer an incorporation "subsidy" to out-of-state firms to attract many of them.

The reason for this is that, in the incorporation market, differences in product quality are likely to be more important for buyers than reductions in the franchise taxes and fees charged by Delaware. While franchise taxes and related fees are quite meaningful in the aggregate to a small state like Delaware, the cost to each public company incorporated in Delaware is relatively small. Whereas the average franchise tax paid in 1999 by NYSE companies was $\$ 134,000,{ }^{89}$ the median value of publicly traded nonfinancial companies incorporated in Delaware was $\$ 133$ million. ${ }^{90}$

laws to offer the arrangements that firms desire). No writer, however, has provided an explicit explanation for the absence of price competition in the market for incorporations.

89. See Kahan \& Kamar, supra note 15 , at 1225.

90. This figure is taken from the data set used in Bebchuk \& Cohen, supra note 8, a study based on all the firms for which there was data for the end of 1999 in the Compustat database. 
Thus, a reduction in the franchise tax bill appears unlikely to lead a firm that finds network benefits and institutional infrastructure to move to forgo them. In sum, a challenge based on merely offering the same rule but at a lower price is highly unlikely to succeed in attracting a large number of outof-state incorporations.

\section{The Futility of "Limited" Challenge}

In some competitive markets, if a good has various dimensions, a player can hope to gain advantage by offering a product that is superior to others in one dimension. For this reason, scholars have argued that the competition in the incorporation market would ensure that any given rule would be efficient. If the prevailing rule were in any way inefficient, maintained Easterbrook and Fischel, then some state would be able to offer an improvement in terms of this rule and thereby attract incorporations. ${ }^{91}$

In the incorporation market, however, the importance of network externalities and institutional infrastructure implies that it would be futile to challenge Delaware by offering an improvement in corporate governance that is not central or substantial in magnitude. Offering a somewhat better rule on a single issue would not be sufficient to attract companies that otherwise would be incorporated in Delaware. The only challenge that could conceivably threaten Delaware would arise from a "global" challenge - a major effort by a state that would make a commitment to this effort, develop the needed accompanying institutional infrastructure, and offer a sufficient improvement to overcome the network-benefits advantage of the incumbent Delaware.

\section{The Futility of Challenge Unsupported by Managers}

A challenge would likely be successful only if it were to attract a large number of out-of-state incorporations. To begin, only such a challenge would likely generate significant profits. Furthermore, attracting any significant number of out-of-state incorporations would be much facilitated if the challenger were able to offer firms network benefits. As explained below, the need to attract a large number of out-of-state incorporations imposes significant limits on the type of rule improvements that could provide a basis for a successful challenge. In particular, it would be quite difficult for a challenge to succeed unless the challenger offered not only a corporate law system more favorable to shareholders than Delaware's but also one that would be as (or more) favorable to managers as Delaware's.

91. See sources cited infra note 109. 
Potential incorporations in a rival's jurisdiction might come from two sources-first, from companies that will go public in the future and, second, from companies that went public in the past and are presently incorporated in Delaware (or in another state) and might choose to reincorporate in the rival state. ${ }^{92}$ The rival state, therefore, will have a strong interest in luring existing public companies, because at any given point in time, the number of existing public companies is significantly larger than the number of companies expected to go public in the near future. A rival state will thus be able to obtain a substantial number of incorporations within a reasonable period only if it is able to attract not only future public companies but also a considerable number of existing public companies.

The rival state, however, would find it difficult to attract existing public firms by offering rules that would be value-enhancing for shareholders but not attractive for managers. Under prevailing law, management has veto power over reincorporations. ${ }^{93}$ Thus, offering a corporate law system that is better for shareholders but not for managers, say one that would offer managers fewer protections from takeovers, will fail to attract existing companies. Without drawing existing companies, the rival would not be able to capture a large fraction of the market for quite a while, which would preclude the rival from being able to offer network benefits and from being able to recoup its up-front investment. ${ }^{94}$

The analysis above indicates that a rival considering a challenge would likely focus on possible moves that would be favored not only by shareholders but also by managers. Reforms aimed at enhancing shareholder wealth by curtailing managers' private benefits are unlikely to be a good basis for a challenge to Delaware's position. This aspect of the

92. On the importance of reincorporating companies and the implications of the managerial control over reincorporation decisions for the debate on state competition, see Bebchuk, supra note 7 , at $1458-61$.

93. There is no explicit procedure under any state statute for reincorporating. A corporation brought to life under one state's statute can only have life as a corporation of that state. But, practically, a reincorporation can be achieved by having the corporation merged into a shell corporation incorporated in another state. The rules for approving mergers require a vote of shareholder approval but only on proposals initiated by the board. See DEL. CODE ANN. tit. 8, $\$ 251$ (a)-(c) (2001). Our analysis takes the existing allocation of power between managers and shareholders as given. For a proposal to grant shareholders initiative power with respect to certain matters of corporate governance, see Lucian Arye Bebchuk, Empowering Shareholders (2002) (unpublished manuscript, on file with authors).

94. Could this problem be overcome if the rival is sufficiently patient and has a sufficiently long horizon? Problems of credibility and commitment might cause a rival to fail even if it is patient enough (in terms of the amount of time it is willing to wait to recoup its investment) to adopt a strategy targeting only new companies in the hope of eventually getting a large fraction of these companies. To see this, suppose that Delaware currently offers rules that favor managers at the expense of shareholders, because its large fraction of existing companies gives it incentive to do so. If that is the case, the market would expect that, if the rival were to succeed in attracting over time a large number of firms going public, then eventually it would also have incentives to act in the same way as Delaware. Unless the rules are enshrined in the state's constitution, it is difficult to make a commitment not to change rules once you are successful. 
existing state of affairs further adds to the difficulty of mounting a successful challenge. It also provides Delaware with incentives to make sure that managers of Delaware companies are content, an issue to which we will return in the next Part.

\section{E. Delaware's Response and the Stalking Horse Problem}

Thus far, our analysis of the obstacles to a profitable challenge to Delaware's dominance has assumed implicitly that Delaware would not alter its course in response to such a challenge. This assumption, however, is unlikely to hold, which would introduce additional impediments. Confronting a challenge, Delaware is unlikely to sit idle and let its longstanding and profitable dominance disappear. Rather, Delaware will probably respond in whatever way would best serve its interests and, in particular, would make it most likely that it would be able to preserve all or most of its revenues from out-of-state incorporations. ${ }^{95}$

The industrial organization literature has noted that rivals' ability to make a profitable entry depends on the incumbent's ability to respond. In some markets, an entrant can engage in a hit-and-run strategy, moving fast and capturing a large market share or at least covering its entry costs swiftly before the incumbent will be able to adapt and develop responses to the new challenge. ${ }^{96}$ For this to happen, the response time of the incumbent must exceed the period needed for a rival state to mount a challenge and make some significant inroads. ${ }^{97}$

This will not be the case, however, with respect to the incorporation market. ${ }^{98}$ Before a challenger can attract any significant number of incorporations, a substantial amount of time will likely pass. A rival's adoption of rules, its development of institutional infrastructure, and its

95. See TIROLE, supra note 57 , at 350 ("[B]ccause competition destroys industry profits, an incumbent has more incentive to deter entry than an entrant has to enter.'). In fact, it might be the case that Delaware has been engaging in practices to preserve its monopolistic position. See, e.g., Kamar, supra note 15 (suggesting that Delaware law might be litigation-biased in order to prevent other states from mimicking its corporate law).

96. When hit-and-run entry is possible, the threat of entry might be sufficient to discipline an incumbent firm even in a market characterized by economies of scale. See BAUMOL ET AL., supra note 68. The Department of Justice Horizontal Merger Guidelines use the concept of "uncommitted entrants" to refer to firms that can enter the market quickly and without sunk costs. See 1992 Horizontal Merger Guidelines, 57 Fed. Reg. 41,552, 41,554 (Sept. 10, 1992); see also Baker, supra note 52, at 361 (noting, in discussing the Merger Guidelines, that uncommitted entry is hit-and-run).

97. See TIROLE, supra note 57, at 310 (demonstrating the importance of the incumbent's response time within a game theory framework); Michael Spence, Contestable Markets and the Theory of Industry Structure: A Review Article, 21 J. ECON. LITERATURE 981, 986 (1983) (noting that hit-and-run entry is possible only if the time it would take the incumbent to respond is smaller than the period for which the fixed costs of the new entrants are sunk).

98. The problem discussed in this Section was first noted for the incorporation market by Bebchuk \& Ferrell, New Approach, supra note 7, at 154-55. 
attracting of incorporations will all take time and will all be rather visible to Delaware. Thus, a rival cannot surprise Delaware and attract a substantial number of out-of-state incorporations before Delaware gets a meaningful opportunity to react. Hit-and-run entry is not possible in the market for incorporations.

The fact that Delaware will be able to respond and adapt is important for assessing the profitability of a rival's challenge. A rival seriously considering a challenge to Delaware would have to take into account what Delaware's response to the challenge would likely be.

Suppose that a rival considers challenging Delaware by offering a different set of rules. Suppose also that the rules are sufficiently better than Delaware's so that, if Delaware sat idly, firms would move en masse out of Delaware. The rival will have to take into account that, confronting such a challenge, Delaware might elect to mimic and match the rival's moves, which would be publicly known. The rival would be able to hide neither its intention to challenge Delaware nor the particular steps it contemplates. ${ }^{99}$ Moreover, new statutory rules of corporate law are easy to emulate. ${ }^{100}$ Hence, knowing what new statutory rules have been put forward by the rival, and recognizing that they have substantial appeal to firms, Delaware will respond to the challenge by matching with the same rules. Given its initial advantage over rival states in terms of network benefits and institutional infrastructure, Delaware will be able to defeat the rival and maintain its dominant position. ${ }^{101}$

Thus, given Delaware's expected response, the rival's investment and effort would not turn out to be worthwhile. ${ }^{102}$ To be sure, the rival would

99. See TiROLE, supra note 57 , at 351 (stating that a monopoly is more likely to persist if the incumbent has access to the rival's technology and sufficient time to preempt the rival, because under these conditions the incumbent can duplicate the rival's strategies).

100. See Kamar, supra note 15, at 1929 (arguing that Delaware's corporate law is indeterminate to prevent other states from replicating it); see also Wilmington City Ry. Co. v. People's Ry. Co., 47 A. 245, 251, 254 (Del. Ch. 1900) (stating that Delaware has adopted the corporate legal precedents of New Jersey). Our analysis assumes that the rival state improves upon Delaware only by providing a superior set of rules and not by improving upon Delaware's legal infrastructure.

101. Somewhat ironically, supporters of corporate federalism have pointed out that Delaware has adopted this strategy. See, e.g., Carney, supra note 50, at 741-42 (finding that Delaware, although not the first mover on most corporate law changes, is a quick follower of successful innovations); Romano, supra note 38, at 846 (noting that "when Delaware is not the pioneer of a corporate law innovation, it is among the first to imitate"). Romano argues, however, that this pattern of response by Delaware supports the current regime of corporate federalism, because it demonstrates Delaware's commitment to constantly improving its corporate law. See id.

102. Cf. Aaron Edlin, Stopping Above-Cost Predatory Pricing, 111 YALE L.J. 941, 945 (2002) (proposing a rule under which the monopoly would be prevented from responding to entry with substantial price cuts or significant product enhancements until the entrant has had a reasonable time to recover its entry costs). This proposal is clearly not applicable to regulatory competition among states. Yet, it is premised on recognition of a similar problem to the one we discuss-namely, that the incumbent's ability to respond might inhibit entry even when the incumbent is at present making supracompetitive profits. 
have the effect of influencing Delaware to adopt better rules. But the rival itself would not gain from such an outcome. Rather, the rival would merely serve as a stalking horse, and its investments would not be recouped. ${ }^{103}$ Anticipating such an outcome, the rival would elect not to mount a challenge in the first place. This factor adds to the ones we have previously discussed in discouraging challenges to Delaware's position, making this position a very secure one.

Moreover, Delaware's ability to respond might adversely affect a challenger even assuming that it would succeed in attracting a significant number of out-of-state incorporations. Assume that a rival state overcomes all the difficulties we have explored thus far and captures half of the market share currently held by Delaware. At first glance, this would ensure that the successful rival state would enjoy half the monopoly profits currently captured by Delaware. As we shall presently explain, however, this will not necessarily be the case.

A state capturing half of Delaware's current market share would capture half of Delaware's monopoly profits only if the overall level of monopoly profits will remain unchanged notwithstanding the successful entry by this state. Delaware's likely response to a successful challenge, however, makes the constant-level-of-profits assumption unlikely. Once both states are established in the market, with both of them having sunk investments, competition would drive prices and profits down. Thus, a challenger that captured half of the market would not be able to capture half of Delaware's current profits. The price competition following a successful challenge would reduce total profits in the market to lower levels, and this would hurt not only Delaware but also the challenger itself. ${ }^{104}$

This process of price competition and the reduced level of profits will, ex ante, reduce the level of profits a rival state can expect to capture following a successful challenge. The prospect of reduced profits, in turn, further discourages states from mounting a serious challenge to Delaware in the market for out-of-state incorporations.

\section{ImPlications for Assessing the Performance of STATE COMPETITION}

The preceding Parts have shown that Delaware enjoys a monopolistic position in the incorporation market, and that barriers to entry and other

103. See DENNIS W. CARLton \& JefFrey M. PERLOFF, MODERN INDUSTRIal ORGANIZATION 79-80 (3d cd. 2000) (recognizing that the combination of large-scale entry investments and the risk of strategic response by the incumbent provides disincentives for potential entrants because it increases the expected loss).

104. See TIROLE, supra note 57, at 314-16 (analyzing the effect of postentry price competition on the level of industry profits). 
structural factors cast substantial doubts over the ability of other states to challenge successfully Delaware's lead. We now turn to assess the implications of the above analysis for evaluating the performance of the current system of federalism. Given the weakness of competition, how well will the incorporation market work? And, if it works imperfectly, in what direction does it push?

Our analysis implies that Delaware and other states are situated quite differently and should not be analyzed in the same way. Delaware is actively in the business of making profits from the incorporation business, but, because of the structural features we have analyzed, it faces a limited threat and thereby enjoys a monopoly position. Other states, for which challenging Delaware's position is not a viable option, are not in the same business. Although these two situations are quite different, in both of them states do not face, and are not motivated by, incentives of the type envisioned by supporters of state competition. We shall discuss below each of the situations and the rules that it can be expected to produce. Section A considers Delaware, the market's leader, and Section B discusses other states.

\section{A. Delaware's Incentives and Product}

\section{The Monopolist's Objectives}

Supporters of corporate federalism argue that the competition among states provides Delaware with powerful incentives to offer the most valueenhancing set of corporate law rules in order to attract and retain incorporations. ${ }^{105}$ Given its monopoly position, however, Delaware might face a set of incentives that differ from the ones that it would confront in the presence of a substantial competitive threat.

Providers in a monopolistic situation generally do not behave in the same way as do ones that face a strong competitive threat. Thus, given its monopoly position, Delaware has incentives to work (i) to maintain its monopoly and (ii) to maximize its profits from its monopolistic position.

Delaware's motivation for preserving its monopoly is clear. After all, as we have seen, this monopolistic position enables Delaware and its citizens to make substantial supracompetitive profits. ${ }^{106}$ To be sure, as we have seen

105. See, e.g., Frank H. Easterbrook, Antitrust and the Economics of Federalism, 26 J.L. \& ECON. 23, 34-35 (1983) (arguing that competition among states leads them to enact that set of laws most beneficial to the relevant population); Frank H. Easterbrook, Managers' Discretion and Investors' Welfare: Theories and Evidence, 9 DEL. J. CORP. L. 540, 564-71 (1984) (arguing that states that make the choice of rules most beneficial to investors will attract incorporations).

106. See supra Section III.E; see also TIROLE, supra note 57 , at 350 ("[B]ecause competition destroys industry profits, an incumbent has more incentive to deter entry than any entrant has to enter."). 
earlier, barriers to entry, network effects, large sunk costs, managerial control over reincorporation decisions, and the risk of strategic response by Delaware will deter rival states from mounting a meaningful challenge to Delaware in the ordinary course of events. Delaware's concern, however, is to avoid the type of situation that could somehow put its monopoly in doubt. It has an incentive to avoid the circumstances that could make feasible an all-out effort by another state to oust it as the market's leader. Delaware similarly has an incentive to prevent circumstances that could give rise to a possibility of federal intervention that would take away or undermine its position. ${ }^{107}$

Furthermore, Delaware has an incentive to increase the revenues it can derive from its monopolistic position. After all, what good is a monopoly position unless you can take advantage of it? As the race-to-the-top scholars contend, the profit-maximization objective guiding firms in a competitive market leads to optimal results. In contrast, as the industrial organization literature recognizes, the profit-maximization objective guiding monopolies might produce suboptimal outcomes. ${ }^{108}$

\section{The Monopoly's Slack}

Recall the argument made by supporters of state competition, such as Easterbrook and Fischel, according to which state competition would drive states to do the best on each and every rule. On this view, a presumption of efficiency applies to each and every rule produced by state competition. ${ }^{109}$

107. See William W. Bratton \& Joseph A. McCahery, Regulatory Competition, Regulatory Capture, and Corporate Self-Regulation, 73 N.C. L. REV. 1861, 1899-901 (1995) (arguing that the threat of federal intervention affects Delaware's law); Eisenberg, supra note 37, at 1512 (arguing that the threat of federal intervention provides Delaware with an incentive not to lead in the adoption of management-biased rules).

108. Thus, the quality of a good produced by the monopoly might be nonoptimal compared to the quality of a good produced by a competitive firm, because the monopolist is concerned with the effect of changes in its output on price, whereas a competitive firm is not. A monopolist can thus either undersupply or oversupply quality. See, e.g., TIROLE, supra note 57, at 100-01; see also Romano, supra note 27 , at 2387 (relying on this observation to argue against a mandatory regime of federal securities regulation).

109. See EASTERBROOK \& FISCHEL, supra note 6, at 81, 86 (arguing, with respect to corporate voting arrangements, that, given the dynamics of state competition, enduring practices of companies "are the best evidence of what constitutes the optimal allocation of resources on voting procedures" and concluding that greater shareholder access to the proxy machinery is undesirable on the grounds that if greater access were beneficial, "it would be adopted by the firms themselves or by state law"); POSNER, supra note 30 , at 458 ("Competition among states to attract corporations should result in optimal rules of corporate law."); Frank H. Easterbrook \& Daniel R. Fischel, Voting in Corporate Law, 26 J.L. \& ECON. 395, 398 (1983) ("[S]tates' legal rules generally provide investors with the sort of voting arrangements they would find desirable if contracts could be arranged and enforced at low cost.... Our conclusions on federal rules are otherwise, reflecting, perhaps, the power of competition among jurisdictions...."); Fischel, supra note 24, at 919-20 (arguing that Delaware has achieved its prominent position because its corporate law maximizes shareholders' welfare). But see EASTERBROOK \& FISCHEL, supra note 6, at 215,218 (emphasizing that they do not argue that "all aspccts of Delaware's corporate law are 
To be sure, this presumption is not conclusive but rather rebuttable, as states aspiring to adopt value-enhancing arrangements might still make mistakes. ${ }^{110}$ But this presumption, so the argument goes, should be used as a starting point for an assessment of a state law rule.

This presumption, however, is not warranted with respect to the rules produced by a state like Delaware that, given the substantial barriers to entry and incumbency effects, enjoys a strong monopoly position. As explained earlier, Delaware is not subject to a meaningful threat of entry or of expansion by rival states. Thus, it is no longer the case that each shortfall in the quality of the corporate law offered by Delaware would trigger an immediate loss of market share. To be sure, the range within which Delaware can move without undermining its position is not unlimited. But Delaware has substantial room to take actions that would not be optimal but would not hurt its leading position. As a result, Delaware does not have an incentive to do the very best on each and every dimension.

In the language of industrial organization, the above argument indicates that-as is the case often with monopolies-Delaware's monopolistic position provides it with slack. The slack reflects the substantial range within which the monopoly might engage in suboptimal behavior without triggering a loss of market share. For this reason, as empirical studies confirm, monopolies tend to produce less efficiently than players in a competitive market. ${ }^{111}$

Research in industrial organization has identified several reasons as to why monopolies might operate less efficiently than firms in competitive markets. ${ }^{12}$ In our context, the reason that seems to be most important is the weaker incentives of a monopoly to offer optimal product quality. ${ }^{113} \mathrm{We}$

optimal" and also asserting that "Delaware can win the race for revenues by being 'best' without being 'optimal"'). These disclaimers, however, have been made in an attempt to reconcile the inconsistency between Easterbrook and Fischel's general position and the wide adoption of state antitakeover legislation. On this inconsistency, see Bebchuk \& Ferrell, Race To Protect Managers, supra note 7, at 1195-97; Robert M. Daines \& Jon D. Hanson, The Corporate Law Paradox: The Case for Restructuring Corporate Law, 102 YALE L.J. 577, 584-89 (1992) (book review).

110. See, e.g., EASTERBROOK \& FISCHEL, supra note 6, at 218 (explaining that "[s]tates no less than managers fish for successful combinations, not knowing what the market really wants").

111. See, e.g., Alison Green \& David Mayes, Technical Inefficiency in Manufacturing Industries, 101 ECON. J. 523 (1991) (finding that an increase in market concentration tends to reduce technical efficiency); Stephen J. Nickell, Competition and Corporate Performance, $104 \mathrm{~J}$. POL. ECON. 724 (1996) (presenting evidence of a correlation between the degree of market competition and the level of productivity growth). The phenomenon of monopolistic slack is also known as "X-efficiency." See generally Roger Frantz, X-Efficiency and Allocative Efficiency: What Have We Learned?, 82 AM. ECON. REV. PAPERS \& PROC. 434 (1992); Harvey Leibenstein, Allocative Efficiency vs. "X-Efficiency," 56 AM. ECON. REV. 392 (1966) (introducing the concept of "X-efficiency" and exploring its economic implications).

112. See CARLTON \& PERLOFF, supra note 103, at 93 (discussing reasons why a monopoly might produce less efficiently than a competitive firm).

113. See Leibenstein, supra note 111. Alternative explanations have been offered for the tendency of monopolies to be less efficient than competitive firms. Some argue that this is 
focus on this reason because it goes to the heart of the claims offered by supporters of state competition as a basis for their highly favorable view of the rules produced by it. With a weak competitive threat, Delaware cannot be relied upon to produce generally value-enhancing rules. It might just muddle through and avoid terrible outcomes.

Furthermore, in our context, there are two additional problems beyond the monopolist's limited incentive to exert effort to get it right. The goals of maintaining its monopoly position and increasing profits from it might lead Delaware to bias its laws in favor of managers and in favor of open-ended standards. We shall now turn to discuss each of the problems in turn.

\section{Managerial Favoritism}

Our earlier analysis indicated the importance of holding a large market share. Because the incorporation market is characterized by economies of scale and network externalities, it would be important for a rival state mounting a challenge to Delaware to attract quickly a sufficiently large number of incorporations. Attracting such a critical mass of incorporations is necessary for the rival state to offer companies the network benefits currently provided by Delaware. Thus, as long as a rival cannot realistically hope to grab before too long a sufficiently large fraction of the market, the mounting of a challenge to Delaware's dominance is substantially discouraged.

This makes it especially important for Delaware to make sure that the large stock of firms already incorporated in Delaware remains loyal even in the presence of a challenge by a rival state. Delaware has a substantial early-lead advantage by starting with the lion's share of the market for outof-state incorporations. As long as Delaware holds on to its existing companies, a rival cannot realistically expect to attract a large mass of incorporations within a reasonable time frame. Even if the rival succeeds in attracting most of the companies that will go public in the future and incorporate outside their home state, it will take the rival many years to build a large stock of incorporations.

Conversely, if Delaware were somehow to lose a substantial fraction of its existing stock of companies, the cost to it would exceed the forgone revenues from the companies that move away. Such a migration out of

because of the absence of yardstick competition-competitors against which to measure performance. See TIROLE, supra note 57, at 75-76. Another branch of the economic literature relates the phenomenon to the principal/agent problem, arguing that the more intense the competition, the more opportunity there is for the principal to compare the performance of the agent to the performance of others. See, e.g., David Scharfstein, Product-Market Competition and Managerial Slack, 19 RAND J. ECON. 147 (1988). On the implications of this latter explanation to corporate governance, see Mark J. Roe, Rents and Their Corporate Consequences, 53 STAN. L. REV. 1463 (2001). 
Delaware would also reduce substantially its incumbency advantages, and thus would make a challenge to Delaware's dominance much easier and thus likely.

One useful strategy for retaining existing companies is ensuring that management is sufficiently content. Because a reincorporation must be initiated by the board, existing Delaware companies are bound to stay as long as management is content with staying. ${ }^{114}$ Furthermore, when companies incorporated in their home state choose to reincorporate elsewhere, managers can significantly influence in which of the out-of-state venues their company will incorporate. ${ }^{115}$

The existing state of affairs thus provides Delaware with incentives to offer rules that managers favor, even if such rules are not the ones most favorable to shareholders. One area of corporate law in which Delaware's tendency to favor managers appears to be manifested is the rules governing hostile takeovers. Managers favor rules that make hostile takeovers more difficult because such rules reduce the likelihood of management being ousted in a hostile takeover and enable management to extract some side payments from the acquirer in negotiated transactions. ${ }^{116}$

Delaware's takeover law, especially its judge-made law, has indeed developed substantial barriers to hostile takeovers. ${ }^{117}$ Overall, managers have been given substantial power to impede hostile takeovers. ${ }^{118}$ Even scholars who belong to the race-to-the-top camp take the view that some of the antitakeover protections accepted by Delaware law go beyond those desirable to shareholders. ${ }^{19}$

Our conclusions in this Subsection complement those of the analysis offered by one of us in earlier work. Proceeding under the premise of active competition for incorporations, this earlier analysis concluded that, to the

114. See supra note 93 . Following a chancery court decision that limited the power of managers to resist a hostile bid, the law firm of Wachtell, Lipton, Rosen \& Katz distributed a now-famous memo to its public company clients suggesting the option of reincorporating outside Delaware. See Jeffrey N. Gordon, Corporations, Markets, and Courts, 91 CoLUM. L. REv. 1931, 1958-62 (1991) (analyzing the memo and its background). The importance to Delaware of maintaining its large stock of incorporations, which in turn would provide a strong impediment to entry by rival states, can explain why such a threat might be meaningful for Delaware's interests.

115. See BAR-GILL, BARZUZA \& BEBCHUK, supra note 7.

116. See Bebchuk, supra note 7 , at 1468 (explaining why managers might be interested in rules restricting takeovers even if such rules fail to maximize shareholder value).

117. For a more elaborate review, see Bebchuk \& Ferrell, Race To Protect Managers, supra note 7 , at 1177-91.

118. See Lucian Arye Bebchuk, John C. Coates IV \& Guhan Subramanian, The Powerful Antitakeover Force of Staggered Boards: Theory, Evidence, and Policy, 54 STAN. L. REV. 887 (2002) (analyzing the entrenching effect of classified boards).

119. See Frank H. Easterbrook \& Daniel R. Fischel, The Proper Role of a Target's Management in Responding to a Tender Offer, 94 HARV. L. REV. 1161, 1164 (1981) (arguing against the use of defensive tactics by targets' boards); Roberta Romano, $A$ Guide to Takeovers: Theory, Evidence, and Regulation, 9 YALE J. ON REG. 119 (1992) (finding that almost all state antitakeover law is unwarranted and harmful); Winter, State Law, supra note 6, at 288 (stating that a regime that facilitates takeovers maximizes shareholders' profits). 
extent that a competitive threat exists, it pushes Delaware to favor managerial interests with respect to an important set of issues. ${ }^{120}$ That argument, however, was based on the direct benefits, in the form of an increase in the franchise-revenue base, associated with retaining a large number of incorporations. In contrast, by dropping the premise of vigorous competition, this Essay has shown that the leading state will likely display managerial favoritism under the weak-competition assumption as well.

\section{Judge-Made, Open-Ended Standards}

Delaware corporate law relies on open-ended standards applied by judges in ways that are highly case-specific. Delaware courts avoid providing bright-line guidance to corporate actors, relying instead on a set of loosely defined tests. ${ }^{121}$ Such tests govern important corporate issues such as the permissible scope of managerial discretion in adopting and applying defensive tactics against hostile takeovers, ${ }^{122}$ the decisions of special board committees when considering motions to dismiss derivative suits, ${ }^{123}$ and the corporate opportunity doctrine. ${ }^{124}$ This indeterminacy creates costly uncertainty. Furthermore, as is suggested by the standard models of trial and settlement, such uncertainty and unpredictability increase the likelihood of litigation. ${ }^{125}$

All this has led observers to conclude that Delaware corporate law is likely overly indeterminate, ${ }^{126}$ and that it likely involves an excessive level of litigation. ${ }^{127}$ An unpredictable and litigation-intensive body of corporate law produces efficiency costs. ${ }^{128}$ First, from an ex ante perspective,

120. See Bebchuk \& Ferrell, Race Ta Protect Managers, supra note 7.

121. See William T. Allen, Ambiguity in Corporation Law, 22 DEL. J. CORP. L. 894, 900 (1997) (noting that Delaware cases are fact-specific applications of grand principles that are difficult to generalize).

122. See Ronald J. Gilson \& Reinier Kraakman, Delaware's Intermediate Standard for Defensive Tactics: Is There Substance to Proportionality Review?, 44 BUS. LAw. 247 (1989).

123. Zapata Corp. v. Maldonado, 430 A.2d 779, 788-89 (Del. 1981) (setting a vague two-step test for deciding motions to dismiss derivative suits); see also Kamar, supra note 15, at 1916-17 (arguing that this test is too ambiguous)

124. See RoBerT CHARLES ClARK, CORPORATE LAW $\$ 7.6 .2$, at 244-46 (1986) (proposing a clearer test); Kamar, supra note 15, at 1916 (same).

125. See Bruce L. Hay \& Kathryn E. Spier, Settlement of Litigation, in 3 THE NEW PalgRave DiCTIONARY OF ECONOMICS AND THE LAW 442 (Peter Newman ed., 1998).

126. See, e.g., Douglas M. Branson, Indeterminacy: The Final Ingredient in an Interest Group Analysis of Corporate Law, 43 VAND. L. REV. 85 (1990); Kamar, supra note 15. But see Romano, supra note 25 (arguing that Delaware rules of corporate law are not overly indeterminate); Leo E. Strine, Jr., Delaware's Corporate-Law System: Is Corporate America Buying an Exquisite Jewel or a Diamond in the Rough?: A Response to Kahan \& Kamar's Price Discrimination in the Market for Corporate Law, 86 CORNELL L. REV. 1257 (2001) (suggesting that Delaware law is not excessively uncertain).

127. See, e.g., Branson, supra note 126, at 111-12.

128. See Kahan \& Kamar, supra note 15, at 1252 (arguing that unpredictability and excessive litigation are inefficient means of price discrimination, because they affect the quality of the 
indeterminate standards undermine the ability of business actors to plan and to know how to act so as to avoid legal liability. ${ }^{129}$ Second, the litigation process itself is costly ex post, consuming resources and effort on the part of plaintiffs, defendants, lawyers, and courts.

This indeterminacy feature of Delaware corporate law has attracted the attention of corporate law scholars, who have tried to explain it. Of course, increasing the volume of corporate litigation enables Delaware to capture higher revenues from incorporations. ${ }^{130}$ But why would Delaware choose to increase its revenues through increasing the level of litigation when it could simply raise franchise taxes instead? ${ }^{131}$

Scholars have advanced several explanations as to why Delaware law has taken such a form. Using a public-choice perspective, Jonathan Macey and Geoffrey Miller have argued that this feature of Delaware law serves the interests of the Delaware corporate bar, which has substantial influence on the state's corporate law. ${ }^{132}$ Kamar has argued that Delaware's reliance on open-ended standards that are applied in case-specific ways makes it difficult for rival states to duplicate what Delaware does in resolving cases, thus excluding these rival states from the network benefits offered by Delaware. ${ }^{133}$ Finally, Kahan and Kamar have recently argued that this feature of Delaware law enables Delaware to engage in price discrimination. Whereas raising franchise taxes will affect all companies, regardless of the value they attach to Delaware corporate law, so the argument goes, increasing the amount of litigation will affect only those companies that are more likely to engage in legal disputes over corporate matters, companies that in turn likely assign a higher value to incorporating in Delaware. ${ }^{134}$

underlying product-Delaware corporate law); Ehud Kamar, Shareholder Litigation Under Indeterminate Corporate Law, 66 U. CHI. L. REV. 887 (1999) (discussing the costs of indeterminacy in corporate law).

129. See Kamar, supra note 15, at 1919.

130. See Kahan \& Kamar, supra note 15, at 1242-48 (explaining that this feature of Delaware law enables it to engage in the practice of price discrimination); Macey \& Miller, supra note 72 , at 469 (arguing that increasing the volume of litigation serves the interests of the local bar in increasing their fees). Other scholars, however, have argued that this indeterminacy serves an important function in regulating corporations. See, e.g., Fisch, supra note 15 (arguing that indeterminacy increases the value of Delaware corporate law, because it enables its judges to exercise lawmaking powers); Edward B. Rock, Saints and Sinners: How Does Delaware Corporate Law Work?, 44 UCLA L. REV. 1009 (1997) (arguing that the fact-specific nature of Delaware corporate law enables courts to shape the social norms goveming managerial behavior).

131. See Macey \& Miller, supra note 72 , at 498 ("If the state were acting as a pure profit maximizer, it would attempt to minimize the indirect costs and maximize the direct costs of Delaware incorporation.").

132. See id.

133. Kamar, supra note 15 , at 1929-32.

134. Kahan \& Kamar, supra note 15, at 1242 ("Companies that are involved in litigation or undertake transactions that may result in litigation are the ones assigning the highest value to incorporating in Delaware."). 
Our analysis suggests an alternative, possibly complementary, way in which the indeterminacy feature of Delaware law serves Delaware's interests. The reliance on open-ended, and highly case-specific, judicial decisions benefits Delaware by reducing the threat of federal intervention, which presents, as we have explained, perhaps the most serious threat to Delaware's dominance. We should stress that we wish merely to note this potential benefit, and we do not argue that, or take any view on, whether in fact it has motivated any Delaware players.

Legal uncertainty serves to make less salient two aspects of the existing state of affairs that might help trigger federal intervention. First, the uncertainty of Delaware law disguises the extent to which Delaware's law favors managers over shareholders. ${ }^{135}$ Explicit, bright-line rules favoring managers could conceivably encourage shareholder groups to push for federal intervention. In contrast, indeterminate standards applied by courts in case-specific ways make the extent to which Delaware's law favors managers much less salient. The indeterminacy always leaves some chance in most cases that Delaware's chancery court will intervene in favor of shareholders. Even a few isolated decisions against managers might be sufficient to disguise and make less conspicuous the managerial favoritism that is actually at work.

Furthermore, the flexibility of the open-ended standards enables Delaware case law to develop in directions that are responsive to the fear of federal intervention without the visible change in course that would be involved in a legislative amendment. When the lax attitude of state law toward corporate freezeouts led to significant calls for federal intervention in this area, ${ }^{136}$ the Supreme Court of Delaware issued the Singer decision, which imposed, based on the open-ended fiduciary principles of Delaware corporate law, greater limits on such freezeouts. ${ }^{137}$ Similarly, even after more than fifteen years of application and development, the Unocal standard for reviewing takeover defenses is sufficiently flexible and open-

135. The importance of appearance and salience is stressed in another corporate governance context by Bebchuk, Fried, and Walker. Lucian Arye Bebchuk, Jesse M. Fried \& David I. Walker, Managerial Power and Rent Extraction in the Design of Executive Compensation, 69 U. CHI. L. REV. 751 (2002). That work analyzes how managers can benefit from, and might seek, compensation structures that disguise the extent to which rents are extracted.

136. Among other things, the Second Circuit sought to provide minority shareholders with a federal cause of action in Green v. Santa Fe Industries, Inc., 533 F.2d 1283 (2d Cir. 1976). The Supreme Court reversed the decision, holding that deception is needed for such a federal cause of action. Santa Fe Indus., Inc. v. Green, 430 U.S. 462 (1977). Citing Cary's famous article on the race to the bottom, however, the Supreme Court put some heat on Delaware by observing that "[t]here may well be a need for uniform federal judiciary standards to govern mergers such as that challenged in this complaint." Id. at 479-80. For an account of the development of Delaware's freezeouts doctrine that suggests that the fear of intervention played a key role, see RONALD J. GILSON \& BERNARD BLACK, THE LAW AND FINANCE OF CORPORATE ACQUISITIONS 1237-315 (2d ed. 1995).

137. Singer v. Magnavox Co., 380 A.2d 969 (Del. 1977). 
ended to permit Delaware courts, should they elect to do so, to ground in it substantial tightening or loosening of such defenses. ${ }^{138}$

Finally, reliance on judge-made law reduces the extent to which applying Delaware corporate law for most of the country's large firms is viewed as arbitrary and illegitimate. If Delaware corporate law were largely set by Delaware's legislature-the political representatives of less than onethird of a percent of the citizens of the United States-Delaware's dominance in setting national corporate law would appear more problematic. Legislative decisions are viewed as reflecting political choice whose legitimacy is drawn from the fact that the legislators represent those affected by the choices. If Delaware's corporate law were mainly set by the legislature, then the affairs of most investors in U.S. public companies would be decided by the political representatives of a tiny fraction of the citizenry. In contrast, opposition to Delaware's dominance would be weaker if the Delaware arrangements were largely the product of Delaware's apolitical courts, which are quite professional, sophisticated, and respected.

\section{Federal Intervention as Delaware's Constraint}

As we noted, the weak-competition account indicates that, rather than the actions of other states, perhaps the main threat to Delaware's monopoly position comes from the threat of federal intervention. Should Delaware go too far in the direction of favoring managers and controllers, and do so in a sufficiently visible fashion, some federal officials (the federal courts, the SEC, or Congress) might intervene and adopt federal rules to govern some corporate law issues (or, in the worst-case scenario, to replace state corporate law altogether). As long as such deviations from shareholder interests produce a risk of federal intervention, this threat will provide Delaware with some positive incentives.

This threat, however, does not provide adherents of the current form of state competition with support for their views. To begin, this constraint is hardly a tight one. Failure by Delaware to serve shareholder interests might trigger federal intervention only if it is sufficiently substantial and salient so as to move the relevant federal officials to take action and if Delaware does not get a chance to diffuse such a threat before it materializes. Thus, the threat of federal intervention, while placing some limits, clearly provides Delaware with a substantial slack to stray away from shareholder wealthmaximization without triggering the feared federal action.

138. Unocal v. Mesa Petroleum Co., 493 A.2d 946 (Del. 1985). For a discussion of how Delaware courts could move this way by an appropriate interpretation of Unocal, see Bebchuk, Coates \& Subramanian, supra note 118. 
Secondly, to the extent that Delaware is acting in shareholders' interests because of the federal intervention constraint, this benefit should not be attributed to the forces of competition but rather to the discipline provided by a potential federal fiat. Note that this constraint works in a positive direction only to the extent that the federal government can be expected to identify corporate governance arrangements that would harm shareholders. And in such a case, there is a far better way to use the federal government to discipline and provide incentives to Delaware.

Under the choice-enhancing form of federal intervention that Part V will discuss, there would be a federal incorporation option as well as a switching rule that empowers shareholders to determine the state to whose corporate law their company would be subject. Such intervention would have better consequences than actual and threatened federal intervention in the form of mandatory federal rules. First, the federal option would be there as a constant, rather than as an occasional, threat. Furthermore, and importantly, whereas federal intervention in the form of mandatory rules might sometimes make matters worse when federal officials impose a worse arrangement than the displaced state law arrangement, choiceenhancing intervention would never have such an undesirable effect; companies would be subject to federal rules only if and when their shareholders judge these rules to be superior to those of Delaware (as well as to those of other states).

\section{B. States Other than Delaware}

\section{Limited Innovation and Experimentation}

Some early supporters of corporate federalism argued that competition among the states spurs corporate law innovation, ${ }^{139}$ and that it leads states to offer a rich menu of options for companies with varying needs. ${ }^{140}$ More recently, however, commentators have shown that the corporate laws offered by the states are in fact very similar. ${ }^{141}$ Furthermore, most

139. See, e.g., Romano, supra note 38 , at 844 .

140. See POSNER \& SCOTT, supra note 28 , at 11 (suggesting that Delaware specializes in charters for large public corporations); Baysinger \& Butler, supra note 28 (arguing that variations in corporate codes match divergent companies with varying capital structures).

141. See Bebchuk \& Ferrell, New Approach, supra note 7, at 129-30 (showing, for example, that the takeover laws of the states are rather similar to, but different as a whole from, the British City Code); Carney, supra note 50, at 729-34; John C. Coffee, Jr., The Future as History: The Prospects for Global Convergence in Corporate Governance and Its Implications, 93 NW. U. L. RFV. 641, 702 (1999) ("[T] he best documented finding in the empirical literature on the U.S. corporate chartering competition is that a high degree of uniformity has emerged in American corporate laws."); Roberta Romano, The State Competition Debate in Corporate Law, 8 CARDOZO L. REV. 709, 709 (1987) (finding "substantial uniformity across the states"). 
innovation in the field of corporate law is actually done by Delaware, while other states generally do not attempt to innovate. ${ }^{142}$

The weak-competition account that we have put forward provides an explanation for the lack of incentives for states to make such investments. We have seen that states other than Delaware generally do not derive revenues from their incorporation business. This is a service they offer essentially for free. For these states, attracting a large number of incorporations by improving their corporate law cannot serve as a motivation for investing in innovation.

It might be argued that the potential benefits to a state from developing arrangements that better serve shareholders are not limited to increasing revenues by attracting more incorporations. Rather, so the argument goes, some of the benefits of a good corporate law would flow directly to the citizens of the state, thus producing an incentive for the state to innovate. Yet, shareholders of publicly traded companies are distributed across the country, and sometimes even the world, and are commonly not concentrated in the state of incorporation. Thus, citizens of the innovating state would not capture all or most of these potential benefits from innovation.

\section{Slack and Managerial Favoritism}

We have seen that states other than Delaware generally are not guided by the goal of capturing a large fraction of the incorporation market. Such a goal is thus not the force influencing their design of corporate law arrangements. What, then, shapes the content of the corporate law rules adopted by states?

There are probably two groups of actors in each state that play a key role in the design of the state's corporate law system. One group of actors consists of members of the state's bar. The bar usually plays a significant role in choosing and changing the state's corporate law rules. The interests of local law firms lie in having a corporate law system that is sufficiently attractive for incorporation by local firms that they have as clients. These law firms would wish to avoid a system that would force out-of-state incorporation.

The other group consists of firms located in the state and their managers. Local firms are important "citizens" of the state. The firms act through their managers, and the managers are thus the ones who yield whatever political power the firms have. On some issues, where there is no

142. Cf. Romano, supra note 15, at 233-37 (arguing that the patterns of diffusion of corporate law innovations across states are consistent with the dynamics of defensive competition under which, if states "do not follow the leader, they will lose incorporations at the margin"). 
or little divergence of interest between managers and shareholders, managers would wish to have the state adopt the value-maximizing rules. However, with respect to rules that affect substantially the private benefits of managers, such as takeover rules, managers might have different interests.

What kind of corporate law is likely to be produced by this process? To begin with, like Delaware, though for different reasons, other states should not be expected to optimize on each dimension. Some states would not care at all about the number of incorporations. Other states, due to the influence of the local bar, would care about retaining the incorporation of local firms but still would have little incentive to optimize on each possible dimension.

The local firms incorporated in-state are those for which the home-state advantage is sufficiently significant. There is no reason to expect that they are right on the fence; some deviations from optimality would be consistent with their staying in-state - especially when Delaware's corporate law is also characterized by such deviations. In short, the performance of states other than Delaware also is likely to be characterized by "slack." The presumption suggested by supporters of state competition, according to which rules produced by state competition should be presumed to be efficient, should not be applied also to the rules produced by states other than Delaware.

As to managerial favoritism, like Delaware, other states would also be expected to favor managers to some extent and, in particular, to provide substantial protections from takeovers. Such an approach would be clearly desired by the managers of local firms, and it would be consistent with the interests of the local bar. The empirical evidence indicates that providing more antitakeover protections enables states to retain a larger fraction of their local firms. ${ }^{143}$

Thus, like Delaware, other states can be expected to display managerial favoritism. The tendency of Delaware and the tendency of other states to do so would, of course, reinforce each other. Given the managerial favoritism of other states, which would be partly the effect of direct lobbying of local managers in such states, Delaware's interest in a large number of incorporations would not be undermined, but rather would be served, by the provision of antitakeover protections.

\section{IMPLICATIONS FOR THE ROLE OF FEDERAL LAW}

Having examined the implications of the weak-competition account for the performance of state competition, we turn in this Part to explore its implications for the desirable division of labor between state and federal

143. See Bebchuk \& Cohen, supra note 8; Subramanian, supra note 34 . 
law in the corporate area. Section A first considers the conventional choice between state law rules and mandatory federal rules. As we explain, the weak-competition account casts substantial doubt on the advantages that have long been attributed to state law rules and thus on their superiority to mandatory federal rules. Section B then argues that, at the minimum, the weak-competition account implies that the current situation could be improved by federal intervention that would be "choice-enhancing."144 Specifically, we present the case for a federal rule that would govern reincorporation decisions and for a federal incorporation option. Such intervention would introduce stronger and healthier competition than the one currently in place in the market for incorporations.

\section{A. The Uncertain Advantages of State Competition over Mandatory Federal Rules}

The traditional debate between race-to-the-top and race-to-the-bottom scholars has been over the desirability and scope of mandatory federal rules. With the federal securities laws imposing mandatory rules with respect to a certain subset of corporate issues, the debate has been about whether this subset of issues should be expanded or contracted. Supporters of state competition have called for reducing the current scope of federal intervention ${ }^{145}$ and have vigorously opposed any proposal for expanding the role of the federal government. ${ }^{146}$ In contrast, critics of state competition argued that mandatory federal rules might be desirable with respect to corporate issues for which competition might pressure states in undesirable directions.

As to the choice between state law rules and mandatory federal rules, our analysis reduces the attractiveness of the former. A recurring theme voiced by supporters of state corporate law is that, because this law is the

144. The idea of "choice-enhancing intervention" was first introduced by Bebchuk and Ferrell, New Approach, supra note 7, and was subsequently defended and developed by Bebchuk \& Ferrell, Reply to Critics 1, supra note 14, and Bebchuk \& Ferrell, Reply to Critics II, supra note 14. This body of work, however, has grounded the case for such intervention on an analysis that largely accepted the conventional premise that states actively compete for incorporations and showed that, given this assumption, competition might push states in an undesirable direction with respect to some areas of corporate law. In contrast, we present below a case for such intervention grounded in skepticism about the existence of active competition. The arguments made by the above earlier work and in this Essay are complementary in building the case for choice-enhancing intervention.

145. See Stephen J. Choi \& Andrew T. Guzman, Choice and Federal Intervention in Corporate Law, 87 VA. L. REV. 961 (2001) (proposing to abandon the current regime of mandatory federal securities laws in favor of a regime of regulatory competition); Easterbrook \& Fischel, supra note 109 (arguing that states' laws should govern corporate voting); Romano, supra note 27 (proposing to abandon the current regime of mandatory federal securities laws in favor of a regime of regulatory competition).

146. See supra note 6. 
product of active competition among states, it is likely to be superior to the corporate law produced by a monopolistic federal government. On this view, whatever drawbacks state law rules might have, the discipline of competition provides these rules with a powerful and decisive advantage over mandatory federal rules. Whereas a monopoly federal regulator would not be compelled to produce optimal rules, the forces of competition would compel states to do so.

Our analysis, however, casts doubt on the magnitude of this advantage of state law rules. The competitive pressure on states, including the dominant state of Delaware, is actually much weaker than has been previously recognized. States, we have seen, are hardly compelled by competition to provide optimal rules, and Delaware has market power with respect to firms that seek out-of-state incorporation. With the competition as weak as it is, it cannot provide the powerful and decisive advantage over the monopoly federal regulator as supporters of state law have argued. Thus, the weak-competition account questions the basis for this view.

To be sure, supporters of state law rules might respond and argue that weak competition is still better than a monopoly federal regulator. Weak competition, so the argument would go, is better than no competition; weak competition still provides state law rules with some significant advantage over federal rules. However, concluding that this advantage is smaller than previously recognized implies that it is more likely to be outweighed if federal law rules turn out to have some other advantages.

Mandatory federal law rules do offer some advantages over state rules. To start, managers' control over reincorporation decisions leads states to develop a managerial bias, which exists independently of the degree of competition in the incorporation market. ${ }^{147}$ This bias clearly would not apply to a single federal regulator. To be sure, a potential bias in favor of managers might emerge even under a mandatory federal regime as a result of successful lobbying efforts by managers. ${ }^{148}$ States, however, can also fall prey to managerial lobbying. ${ }^{149}$ The key difference between a regime of corporate federalism and a mandatory federal regime is that the managerial bias created by managers' control over reincorporation decisions requires no lobbying effort on behalf of managers. Stated differently, managerial

147. See supra text accompanying notes 119-120 (arguing that managerial bias would exist under either perfect or imperfect competition).

148. See Stephen M. Bainbridge, The Politics of Corporate Governance, 18 HARV. J.L. \& PUB. POL'Y 671, 705-07 (1995) (arguing that Congress is institutionally incapable of corporate governance reforms); Choi \& Guzman, supra note 145, at 974-76 (raising the concern of managerial lobbying of the federal government); Romano, supra note 27 (positing that the federal govemment would be subject to managerial lobbying).

149. The relative success of managerial lobbying on the state level can be seen in the context of state antitakeover legislation. Many such statutes were enacted as a result of lobbying efforts by managers. On several occasions, managers sought protection in the midst of a battle over the control of their corporations. See sources cited supra note 47. 
control over reincorporation decisions would produce this bias even if managers did not spend any effort or resources on lobbying. ${ }^{150}$

Second, the dominant state under the current regime of corporate federalism has an interest in making its corporate laws somewhat indeterminate and litigation-intensive. ${ }^{151}$ The reasons underlying this bias might be the interest in mitigating the risk of federal intervention, in price discrimination, or in reinforcing the dominant state's position by increasing network effects. Whatever the precise reason turns out to be, a federal regulator would not exhibit this bias.

Third, a federal regulator would have, and be willing to devote, more resources for developing and implementing legal rules that would enhance shareholder wealth in publicly traded companies. The resources used for such purposes by the SEC are an order of magnitude larger than those devoted by states for such purposes. As long as Delaware can maintain its dominant position among publicly traded firms, it has no incentive to spend resources on rules that would benefit largely out-of-state shareholders. Other states also do not have an incentive to devote substantial attention to the optimal regulation of publicly traded firms. States are not expected to give direct weight to the interests of out-of-state shareholders, whereas the federal government is expected to take a broader perspective that takes into account the interests of all public shareholders. Accordingly, loyal state officials should be expected to spend less on developing optimal corporate arrangements than would loyal federal officials.

\section{B. Federal Intervention To Invigorate Competition}

\section{Federal Role Without Mandatory Rules}

The above analysis indicates that, even if the choice were only between state law rules and mandatory federal rules, the latter would be more attractive than has been recognized. Many corporate scholars, however, might remain reluctant to favor mandatory federal rules. The preceding analysis indicates that the potential advantage of state law rules, compared with mandatory federal rules, is significantly smaller than has been suggested by race-to-the-top scholars. This advantage, however, cannot and should not be dismissed. State rules do provide a potentially valuable safety valve that protects against huge deviations of corporate law from optimality. ${ }^{152}$

150. See Bebchuk \& Ferrell, Reply to Critics I, supra note 14, at 1003.

151. See supra Subsection V.A.4.

152. See Romano, supra note 27 , at 2387 (arguing that "[w]ith only a national law, there would be no safety valve offered by a competing jurisdiction"). 
Clearly, we have seen that, due to the weakness of competition, state rules might substantially deviate from optimality, say, in favor of managers. There is still a limit, however, on how far these deviations can go. If state rules became terribly inefficient, then at some point, some state might make an effort to provide a better regime, states' limited incentives to do so notwithstanding. If the loss in shareholder value associated with managerial bias became sufficiently large, for example, some state might offer a better regime, and the shareholders of existing companies might overcome their collective action problems and pressure management to reincorporate elsewhere. ${ }^{153}$ Put differently, even when competition is quite weak, it can establish a limit, however weak, to how badly things can go. In contrast, with mandatory federal rules, the safety valve of switching to another state would not be in place to check against very inefficient rules. Certainly, firms would still be able to reincorporate outside the United States, but because foreign reincorporation often entails significant noncorporate costs (such as tax costs), this safety valve might be a costlier one.

The safety-valve advantage of the current regime over mandatory federal rules does not imply that the former is better than the latter. We do not attempt to decide which regime is superior, because it still remains to be determined whether the safety-valve advantage outweighs the advantages of mandatory federal rules discussed above. Our analysis has shown instead that the advantage of the former over the latter is far more uncertain than has been believed. What we can confidently say, however, is that the problems of the current regime we have identified suggest that, at the minimum, it would be desirable for federal law to play a role that falls short of imposing mandatory substantive arrangements.

In particular, it would be desirable for federal law to play a choiceenhancing role that would invigorate competition. ${ }^{154}$ There are two ways in which federal law could serve such a role. First, federal law could establish "switching rules" to govern reincorporation from one state to another, which would ensure that greater weight is given to shareholder interests. Second, federal law could provide an incorporation option.

\section{Federal Regulation of the Switching Rules}

We believe it would be desirable for federal law to adopt a mandatory rule governing the process of firms' reincorporation decisions. Specifically,

153. For example, when Pennsylvania enacted an antitakeover statute that was widely perceived as extreme and excessive, pressure from institutional investors led the majority of Pennsylvania companies' boards to opt out of this arrangement. See ROMANO, supra note 5, at 68; Samuel H. Szewczyk \& George P. Tsetsekos, State Intervention in the Market for Corporate Control: The Case of Pennsylvania Senate Bill 1310, 31 J. FIN. ECON. 3,18 (1992).

154. See Bebchuk \& Ferrell, New Approach, supra note 7, at 150-51. 
a federal process rule should enable shareholders to initiate and approve by a vote a proposal to reincorporate in a different state. ${ }^{155}$

The conclusion that competition in the incorporation market is highly imperfect makes such a rule desirable. As we have shown, the existing rules governing reincorporation decisions give management a veto power over incorporations. This feature of the existing state of affairs reinforces the leading position of the dominant state, as long as it keeps managers content, and thereby weakens competition. Furthermore, this feature introduces managerial favoritism into states' decisions.

A federal mandatory process rule would address two problems involved in the existing state of affairs that we have discussed. First and perhaps most importantly, it would eliminate the managerial favoritism bias introduced by the existing switching rules, which give managers control over the decision whether to have a vote on reincorporation. Under the proposed switching rule, the shareholders' preference would fully determine whether a reincorporation would take place. Given this, making managers happy would no longer enable any state to keep its existing stock of incorporations.

Second, the considered switching rule would make viable a state's effort to capture a substantial market share by offering rules that are beneficial to shareholders but less favorable to managers than existing rules. The switching rule would much increase the pool of companies that such a rival state may realistically hope to attract. As explained earlier, ${ }^{156}$ managerial control over reincorporation decisions renders futile a strategy of attracting existing corporations by offering rules that might make managers worse off. A mandatory process rule would make it possible for states to attempt to attract existing corporations by offering rules that enhance shareholder value. The ability to attract existing corporations will, in turn, enable a rival state to offer some network externalities and to recoup its investment at a quicker pace than under the current rule of managerial control over reincorporation decisions.

\section{Federal Incorporation Option}

In the absence of the barriers to entry discussed in the preceding Part, switching rules that empower shareholders would be sufficient to induce optimal state rules. If we had vigorous competition and shareholders were in control of switching decisions, competition would indeed operate very well. As discussed earlier, however, entry into the incorporation market is discouraged by Delaware's ability to match what the entrant does, thus

155. See id. at $147-49$.

156. See discussion supra Section IV.D. 
undermining the profitability of such an entry. Accordingly, even with good switching rules, Delaware might not face the strong competitive threat that could make it very attentive to shareholder interests.

Competition might be improved by providing a federal incorporation option. ${ }^{157}$ Federal law would provide another jurisdiction under which firms could choose to incorporate. Such a federal incorporation option exists in Canada, where firms can incorporate either in one of the provinces or federally. ${ }^{158}$

Even in the absence of imperfect competition, there should be no reason for a supporter of corporate federalism to oppose a federal incorporation option (as opposed to a mandatory federal regime). Expanding the menu of options available for companies cannot hurt, and might improve, the quality of corporate law. As long as competition for incorporations is viewed as strong and vital, however, the value from adding such an option would seem rather limited. If a value-increasing regime could be developed, it might be argued, the market would offer it. Once the weakness of competition is recognized, however, the case for adding a federal incorporation option becomes strong, indeed compelling.

At first glance, it might be argued that introducing a federal incorporation option would simply add another potential competitor to the fifty others Delaware already faces. This observation might lead one to conclude that such an addition would not affect significantly the vigor of competition. The federal competitor, however, would be a different type of player, with different resources and incentives. Such a competitor might add substantially to the competitive threat facing Delaware.

Recall the analysis suggesting that states might be discouraged from mounting a challenge to Delaware's dominance by the difficulty of recouping a return on their investments and efforts. A challenge might lead Delaware to match whatever improvements are offered by the challenger, and the challenger might then find itself operating as a stalking horse that produced an improvement in corporate law but did not capture any benefit for itself. As long as a state cannot be expected to make sufficient profits from mounting a challenge, such a challenge would not be worthwhile even if it were expected to improve the overall quality of corporate law.

The federal government, however, has different incentives. In considering the benefits of making an effort to improve the quality of the corporate law offered by the federal incorporation option, the federal government would take into account not only the likely effects of this amendment on its incorporation-related revenues, but also the overall effect

157. See Bebchuk \& Ferrell, New Approach, supra note 7.

158. For a discussion of the Canadian federal option, see Douglas Cumming \& Jeffrey Maclntosh, The Role of Interjurisdictional Competition in Shaping Canadian Corporate Law, 20 INT'L REV. L. \& ECON. 141 (2000). 
on the economy. Accordingly, the federal government might make the necessary effort to innovate and improve the quality of corporate law even if such a move would only push Delaware to imitate and thus result in no change in actual incorporation patterns. The ability of the federal government to mount a meaningful challenge would be facilitated by the resources available to the government, including the professional and experienced infrastructure provided by the SEC.

Finally, the experience in Canada supports the prediction that a federal option could substantially influence the outcome produced by competition among jurisdictions. In Canada, the introduction of a federal option has had a substantial impact on the rules offered by the provinces, which have all been induced to adopt the main reforms provided by the federal jurisdiction. $^{159}$

\section{Appeal and Feasibility}

The choice-enhancing form of federal intervention that we endorse should have wide appeal. Even those who strongly believe that the current regime of state competition generally produces optimal corporate laws should have no objection to the introduction of an additional venue for incorporation, because an additional competitor would only expand the set of available choices and thus bolster the competitive process. And they should similarly have little reason to oppose reincorporations desired by shareholders. Thus, at least in theory, the proposed regime of a federal incorporation option clearly dominates the current regime of state competition. ${ }^{160}$

But the superiority of the federal incorporation option from a policy perspective is, of course, not a sufficient condition for its adoption by Congress. Legislation is a political process that is substantially influenced by the dynamics of interest-group politics. The political economy of our proposal, i.e., the extent to which it can realistically expect to be adopted, is beyond the scope of this Essay. Our interest here is in the preliminary policy question of which measures would be worthwhile, as a matter of good public policy, to pursue further. Choice-enhancing intervention, we have concluded, is such a measure.

159. See id.; Ronald J. Daniels, Should Provinces Compete? The Case for a Competitive Corporate Law Market, 36 MCGILL L.J. 130 (1991).

160. See Bebchuk \& Ferrell, New Approach, supra note 7, at 149-51 (arguing that a choiceenhancing federal intervention in takeover law is unambiguously superior to federal nonintervention). 


\section{CONCLUSION}

This Essay has questioned the widely held belief that, whether the race is to the top or the bottom, states vigorously compete to attract incorporations. We have shown that, although this belief is central in current thinking about the process producing corporate governance arrangements, it is in fact incorrect. The competitive threat to Delaware's dominant position, we have shown, is rather weak, and Delaware's position is far stronger and more secure than has been previously recognized. We have also analyzed the structural features of the market for incorporations that explain this state of affairs.

The weak-competition account of state competition that we have put forward has substantial implications for assessing the quality of rules produced by state competition and the desirable role of federal law in this area. This account casts substantial doubt on the extent to which state competition can be relied on - even on the most favorable view of it-to produce optimal corporate rules. Given the highly imperfect nature of competition in the market for incorporations, no presumption of efficiency should be accorded to such rules. This account, furthermore, lends support to concerns that the rules produced by state law are tilted toward managerial favoritism.

Finally, this account strengthens the case for some form of federal intervention; at the minimum, it would be desirable for federal law to invigorate competition by permitting shareholders to initiate and approve reincorporations and by providing a federal incorporation option. Such intervention would produce regulatory competition that is both more vigorous and more focused on the interests of shareholders. By improving the process generating corporate law arrangements, it could provide substantial and lasting improvements in corporate governance and shareholder value. 
$* * *$

Imaged with the Permission of Yale Law Journal 